\title{
Between Basilea and Utopia: Exploring the Impact of Kingdom Theology in US Latinx Pentecostalism
}

\author{
Juan C. Morales
}

Citation: Morales, Juan C. 2021. Between Basilea and Utopia: Exploring the Impact of Kingdom Theology in US Latinx Pentecostalism. Religions 12: 470. https://doi.org/ $10.3390 /$ rel12070470

Academic Editor: Samuel Cruz

Received: 21 March 2021

Accepted: 11 June 2021

Published: 25 June 2021

Publisher's Note: MDPI stays neutral with regard to jurisdictional claims in published maps and institutional affiliations.

Copyright: (C) 2021 by the author. Licensee MDPI, Basel, Switzerland. This article is an open access article distributed under the terms and conditions of the Creative Commons Attribution (CC BY) license (https:/ / creativecommons.org/licenses/by/ $4.0 /)$.
Religion and Society, Union Theological Seminary, New York City, NY 10027, USA; jm3443@utsnyc.edu

\begin{abstract}
This article is a general exploration of US Latinx Pentecostalism's explicit and implicit theology of the Kingdom of God and how it can contribute to US Latinx Pentecostalism's sociopolitical engagement. An overview will be provided of traditional, US Pentecostal Kingdom theology and Kingdom theology in Latin American Liberation Theology. These will be contrasted with US Latinx Pentecostal perspectives. To locate US Latinx Pentecostal theology of the Kingdom of God, this paper will first provide a wide-ranging description of a traditional evangelical hermeneutical process. Afterward, an understanding of the Kingdom that is generally taught and accepted in most evangelical contexts will be discussed. This will be followed by a survey of dominant US Pentecostal theology of the Kingdom of God through the lens of the Assemblies of God doctrinal statements and Pentecostal scholars. The life and work of various Pentecostal ministers and author Piri Thomas will provide a Kingdom perspective of US Latinx Pentecostal practitioners. I will provide an analysis based on their life experiences and some of their writings. The writings of Orlando Costas will set the stage in order to examine the works of other US Latinx Pentecostal scholars. Thereafter, the theologies of Latin American Liberation Theologians Clodivis and Leonardo Boff and others will be surveyed. Before concluding, the article will provide a historical overview of Latinx Pentecostal social engagement in the northeast US with the goal of identifying Kingdom values and priorities.
\end{abstract}

Keywords: Pentecostalism; liberation theology; Latinx and Hispanic Pentecostalism; Kingdom of God; urban ministry; women in ministry

\section{Introduction}

This article will demonstrate that US Latinx Pentecostalism's explicit and implicit theology of the Kingdom of God provides a theological and experiential rationale for effective social and political engagement. To make this case, contemporary, and what can be considered traditional, US Pentecostal Kingdom theology and Kingdom theology in Latin American Liberation Theology will be contrasted with US Latinx Pentecostal perspectives. The differences between the three communities provide useful insight to the analysis. However, there are also commonalities that US Pentecostalism and Latin American Liberation Theology share with US Latinx Pentecostalism. US Pentecostals are tied with US Latinx Pentecostals by a shared doctrinal heritage and practices that go back to the Azusa Street Revival. US Latinx Pentecostals are also tied Latin American liberation theologians by a shared history of US domination and consequent oppression. Both the differences and similarities that each has with US Latinx Pentecostalism expose organic, contextualized perspectives and practices that, contrary to common stereotypes about Pentecostals, engage and address the realities of marginalization, exploitation, and systemic racism that are faced by the communities in which many US Latinx Pentecostal churches are located.

As the US Latinx population continues to grow, it becomes increasingly important to locate the US Latinx Pentecostal community of faith in its theology and practice and to question whether or not its theology is fitting for the social and political engagement that is necessary to address issues of injustice and disenfranchisement in the communities 
where US Latinx Pentecostal churches are located. The US Latinx population continues to be underrepresented at the leadership levels of many fields that facilitate community self-determination (e.g., education, politics). US Latinx Pentecostals can be instrumental in helping their respective communities to obtain a degree of self-determination through an agenda of liberation that is consistent with its theology.

In order to locate US Latinx Pentecostal theology of the Kingdom of God, this paper will first provide a general description of a traditional evangelical hermeneutical process. Afterward, an understanding of the Kingdom that is generally taught and accepted in most evangelical contexts will be described. This will be followed by a survey of dominant US Pentecostal theology of the Kingdom of God through the lens of the Assemblies of God doctrinal statements and Pentecostal scholars R. Hollis Gause, Amos Yong, and Frank Macchia. Reies Lopez Tijerina and Rev. Raymond Rivera will provide a US Latinx Pentecostal practitioner's definition of the Kingdom, while author Piri Thomas provides a layperson's critique. Because Pentecostal practitioners have written little on the subject, I will explore the topic based on their life experiences and some of their available writings. Given his influence on US Latinx Pentecostal scholarship, the writings of Orlando Costas will set the stage in order to analyze the works of US Latinx Pentecostal scholars Drs David Traverso, Samuel Solivan, and Eldin Villafañe. Thereafter, the theologies of Latin American Liberation Theologians Clodivis and Leonardo Boff, Gustavo Gutierrez, Jon Sobrino, and Jose Miguez Bonino will be surveyed, followed by a brief historical overview of Latinx Pentecostal social engagement in the northeast US with the goal of identifying Kingdom values and priorities. The paper will conclude with a summary of the findings.

\section{Evangelical Hermeneutics}

Like their predecessors, the Fundamentalists, Evangelicals adhere to the inspiration of the Scriptures as accepted in the Western Protestant canon. What was birthed within the evangelical movement was the grammatical-historical approach to hermeneutics upon which evangelicals settled 1 (Johnston 1982, p. 33). Fundamentalists insisted on maintaining (1) oracularity - a "dictation theory" of inspiration for the "original writers" of Scriptures (God communicated the exact words of Scriptures which were copied with no errors or diversions); (2) "ultra-inerrancy" and "ultra-infallibility" (Scriptures can and must be used as, for example, history or science textbooks); (3) a "literalist" method of interpretation. For fundamentalists, the Scriptures are to be understood and followed in a formulaic fashion by all generations. The original context of a given pericope is irrelevant (Fackre 1989, p. 120).

Evangelicals generally agree with the primacy of the Scriptures. When discussing his process for developing theology, evangelical theologian Erickson states, "the first step in our theological method will be to gather all relevant biblical passages on the doctrine being investigated." (Erickson 1985, p. 66). Johnston suggests, however, that in contrast to the Fundamentalists, Evangelicals were willing to widen the options available in the process of interpretation of the Scriptures by taking into account the literary and historical contexts of a given pericope (Johnston 1982, p. 34). Thus, in order to develop an evangelical definition of the Kingdom, the Scriptures serve as the foundational authority while taking into account historic and literary contexts. When discussing evangelical hermeneutical approaches, the role of what can be characterized as an epistemic individualism of sorts cannot be minimized. While it is beyond the scope of this article, this aspect of evangelical hermeneutics needs further exploration. ${ }^{1}$

\section{An Evangelical Definition of the Kingdom of God}

In order to explore how this hermeneutical process relates to the development of theology, I will rely primarily on the Assemblies of God (AG) doctrinal and position papers, as the AG is an evangelical denomination that is also Pentecostal. The AG central statement on the Kingdom of God begins by defining the Hebrew and Greek meanings of the word "kingdom" based on Psalm 22:28, 1 Jn. 5:19 and Revelation 111:17-18, primarily as "the authority, reign, or rule of a king." ${ }^{2}$ 
There are other terms used in Scriptures to refer to the Kingdom of God, some of which are also descriptive. These include Kingdom of Priests (Exodus 19:6), the Kingdom of Heaven (Mt.18:3), the Righteous Kingdom (Psalms 45:6, Isaiah 32:1, Jeremiah 23:5, and Hebrews 1:8-9), the Everlasting Kingdom (Daniel 2:44, 7:14, and Luke 1:33), the Universal Kingdom (Psalms 2:8, 72:8, Zechariah 14:9, and Revelation 11:15), the Kingdom not if this system (John 18:36), Christ's Kingdom (Mt.13:41, 18:4, 20:26-28), and Kingdom of Christ and of God (Ephesians 5:5).

In speaking of the Kingdom of God, a word must be mentioned regarding the temporal nature of the Kingdom. There is a tension between the understanding of the Kingdom as having been "among us" through Jesus Christ, being present, and as having yet to be actualized. The tension comes as various streams of the Church attempt to define to what extent the Kingdom is made visible or realized in the present, how its visions of utopian peace and justice are to be understood and actualized, and what may be the relationship of the Kingdom and the Church. Millard J. Erickson provides what can be considered a generally accepted evangelical definition of the Kingdom of God. He states,

The church is a manifestation of the kingdom or reign of God. It is the form which that reign takes of earth in our time. It is the concrete manifestation of God's sovereign rule in our hearts ... The kingdom can be found wherever God rules in human hearts. But more than that, it is found wherever his will is done ... The church is only one manifestation of the kingdom. (Erickson 1985, p. 1042)

This definition places a priority on the church as the institution through which God exerts sovereign rule. However, the Kingdom here can be understood as taking an individualistic turn. For Erickson, God's rule is exerted individually, because the Kingdom is a manifestation in our hearts and is found if God rules in the heart of the person. "There is no statement anywhere in the New Testament that there is any other basis of salvation." (Erickson 1985, p. 1043). As we will see shortly, Pentecostals believe that this will be the case in the Parousia. Erickson gives no indication as to when this is to occur. However, regarding the full manifestation of the Kingdom, Erickson states,

Jesus kingship ... is not of this world (John 18, p. 36). In saying this to Pilate, Jesus undoubtedly meant that his kingdom would not be established upon earth at that time. But because there is to be a future earthly kingdom of God, it appears that Jesus had more in mind, namely, his kingdom does not derive its power from such earthly forces as would fight for him. (Erickson 1985, p. 646)

The understanding of the Kingdom is, therefore, what has often been interpreted as an individualistic present followed by a disconnected future. The praxis of US Latinx Pentecostal practitioners as well as the scholarship of some within the community have called for a more expansive view of the Kingdom.

\section{A Pentecostal Definition of the Kingdom of God}

The AG position paper presents a traditional Pentecostal definition of the Kingdom of God. The position paper depends to a greater extent on the New Testament than on the Hebrew Scriptures. This is typical in Evangelical theology, as the New Testament is generally seen as the fulfillment of the Hebrew Scriptures by the Evangelical community. ${ }^{3}$ According to the position paper, the Hebrew Scriptures make one reference to the "Kingdom of the Lord" in I Chronicles 28:5. Hereafter, they make reference to the notion of the authority and power of the Kingdom in the Psalms, I Chronicles, and Isaiah. ${ }^{4}$ The New Testament uses a number of terms when making reference to the Kingdom of God. The AG position paper makes eight references to the Kingdom. ${ }^{5}$ These include the kingdom of heaven (Mt.6:33), of the son of man (Mt.13:41), of the Son (Lk.22:30), of Jesus (Rev.1:9), of Christ Jesus (2 Tim.4:1), of Christ and God (Eph.5:5), and of our Lord and of His Christ (Rev.11:15).

As does evangelicalism in general, Pentecostal theology affirms that the Kingdom is the sphere of God's rule (Ps.22:28). In the Kingdom, Jesus is eternal King, as promised to 
King David (Lk.1:31-33). While ministering on earth, Jesus' message was "the kingdom of heaven is near" (Mt.4:17). The Disciples of Christ are rescued from the kingdom of darkness to the kingdom of the Son (Col.1:13). To these, the secrets of the Kingdom are revealed (Mt.13:11) in parables, but they would be fully revealed in the eschaton (Mt.13). The authority of the Kingdom is given to the church (Mt.13:18-19), and with that authority, they are to proclaim the good news of the Kingdom (Mt.10:7). Not only have disciples been brought into the Kingdom of the Son, but the Kingdom is now- "within you" (Lk.17:21). Through the Spirit, the church continues the Kingdom ministry of Jesus.

Regarding eschatology, Pentecostal theology teaches that the Kingdom is "not yet" but will be fully revealed in Parousia (Lk.21:27-31). The Church cannot do anything to bring the Kingdom except to pray "thy Kingdom come" (Mt.6:10). The Church has been brought into the Kingdom, has the Kingdom within, but it is also a "harvest" of Kingdom (Mt.13:41-43).

Pentecostal theology is developed by taking a Biblical-literalist approach to its hermeneutics. For example, Pentecostals "understand the biblical description of endtime events to be literal, not symbolic." ${ }^{\prime \prime}$ Although Pentecostals generally believe that the end-times began at Pentecost (Acts 2), the final stages of the end times are a marked period that is distinguishable from any other time within the end-times age. Regarding the eschatological manifestation of the Kingdom, many Pentecostal denominations assume a pre-tribulation Rapture, which is a pre-millennialist theology. The Rapture is the first phase of the Second Coming of Christ. In this phase, the people of God will be taken up from earth, the dead in Christ being resurrected and the living being transformed (I Cor.15:52). This will begin a seven-year period where the anti-Christ will rule. The first three-and-a-half years will be a time of prosperity. Peace will finally have been achieved between the Nation of Israel and its enemies. The second three-and-a-half years will begin with the anti-Christ desecrating the Temple of Salomon and persecuting Israel with a multi-national force (Daniel 9; Mt.25). This force will converge at the Valley of Megiddo at the end of the second three-and-a-half-year period. This confrontation is known as the Battle of Armageddon. At this point, the Second Coming will take place. Christ will appear with the Church and heavenly hosts and will destroy all of Israel's enemies along with the Anti-Christ, the Beast, and the False Prophet. Satan will be bound for a thousand years. Christ will establish a millennial Kingdom (Revelation 20), and at the end of this period, Satan will be released and will again deceive the nations of the earth to rebel against Christ. Satan will be defeated once again, thrown into the Lake of Fire along with his demons for eternity. A final judgment will take place and those who are condemned will spend eternity separated from God; this is the second death. Those who are the People of God will spend eternity with God. Earth will be made anew, and the center of the new earth will be the New Jerusalem. The Kingdom of God and the Reign of Christ will finally be fully established for eternity (Revelation 21, 11:15). In this Kingdom, there will be universal peace within all creation (Is.11:6-9) and humanity will, "beat their swords into plowshares" (Micah 4:3-4).

This narrative, from the Parousia to the final establishment of the basilea, is considered the "classic" Pentecostal interpretation of the end of the age. It is also the prevailing eschatology in most Latinx Pentecostal denominations in the Northeast including the Spanish Eastern District of the Assemblies of God, Iglesias de Cristo Misionera (MI), Concilio Rehoboth, and Concilio de Iglesias Damasco.

Pentecostal scholarship has expanded on the implications of this theology for the life of the church. We will now briefly explore the works of texts written by Pentecostal scholars in order to obtain a sense of where Pentecostal scholarship has found itself and where it is going.

\subsection{R. Hollis Gause}

This survey of R. Hollis Gause's work is based primarily on Gause's reworked Ph.D. dissertation, The Lukan Transfiguration Account. While this work focuses on Jesus' trans- 
figuration, it remains an important analysis of the Kingdom of God from a Pentecostal perspective. An essential aspect of Gause's work for the purpose of this article is his emphasis on the imminence of the Kingdom in Luke's narrative. In his introductory remarks on this aspect of the transfiguration event, he states, "In Luke 9:27, Luke does not speak of the arrival of the Kingdom. Instead, he speaks of seeing the Kingdom" through the transfiguration event (Gause 2020, p. 92). More to the point, he later states that there are two categories of the Kingdom, "those that describe the present form of the kingdom and those that describe the future form of the kingdom." (Gause 2020, pp. 93, 99). However, "in contrast to the Pharisee's expectation of an immediate but yet unseen and unrealized in breaking of the Kingdom (the age to come), Jesus answered here that the Kingdom of God is 'among you.'" (Gause 2020, p. 93). In this last statement, Gause focuses his attention on the imminent character of the Kingdom.

Gause discusses the presence of the Kingdom in the life of Jesus and the role of the proclamation in bringing about the Kingdom (Gause 2020, p. 94). He then discusses the continued presence of the Kingdom from the life of Jesus and his proclamation of the Kingdom to its continued imminence as a result of the coming of the Holy Spirit in Pentecost and the Spirit's continued outpouring on every believer (Gause 2020, p. 95). Of this, Gause states, "after the ascension it is the Holy Spirit that 'constitutes a continuing presence of the Kingdom of God ... Luke regards the Holy Spirit as the mediator of the reign of God." (Gause 2020, p. 94). Gause argues that the Kingdom is "brought into being by the Gospel's proclamation. Prior to the ascension this proclamation is primarily in Jesus, but it is also carried out by his disciples. After the ascension this proclamation is by the action of the Holy Spirit in the Church." (Gause 2020, p. 94).

Gause pays attention to both the immanent and eschatological aspects of the Kingdom. One of the key differences he makes relates to what he refers to as its distinctive character in which the believer lives the eternal life. In contrast, "in this age, though in the Kingdom, the believer receives those things that are related to temporal possessions and relations which have been given up for the sake of the Kingdom of God." (Gause 2020, p. 103). For the Christian community, the holy communion anticipates the age to come and contrasts it with this age. Both, however, relate to experiences of the Kingdom (Gause 2020, pp. 103-4).

There are other events, images, and language that Gause presents as signs that speak to the nature of the Kingdom. The Parousia itself, i.e., the Second Coming of Christ, the eschatological supper, and Judgement Day all foretell what is to come (Gause 2020, pp. 123, 128). However, it is the Transfiguration event in which Moses and Elijah appeared with Jesus in his glorified body while he was with Peter, James, and John and thus made the trans-temporal nature of the Kingdom visibly evident to those that were there (Gause 2020, p. 123). Gause describes this particular event saying,

The Transfiguration was described in Luke as a presentation of the Kingdom of God. This is the fashion in which the Kingdom will appear at the end of the age, but this presentation does not close out this age. It was a presentation of the Kingdom to Peter, John, and James and n envelopment of them in it that did not remove them from this world order ... In the moments of the Transfiguration scene and particularly in the moment of the Shekinah they were in the Kingdom. (Gause 2020, p. 127)

As will be explored below, US Pentecostal Latinx ministry practitioners and scholars understood that the transcendently imminent and eschatological nature of the Kingdom has implications for the Church in society. Further, they perceived that the communal nature of the Kingdom, exemplified by the Holy Communion, a public Parousia, Judgment Day, and the Transfiguration event, arguably has social implications.

\subsection{Frank Macchia}

In his text, Baptized in the Spirit: a global Pentecostal theology, Macchia makes important contributions to Pentecostal theology as he questions and challenges the evangelical subordination of the Spirit to the Scriptures. In this process, he seeks to create a theological space 
that takes into account the manner in which the Spirit's moving is expressed in different parts of the world while maintaining a Pentecostal distinctiveness that has been critical in the revitalization of the Church in the twentieth century (Macchia 2006, p. 25).

Macchia opens the theological space by expanding the definition of one of Pentecostalism's most cherished and distinctive teachings, the baptism in the Holy Spirit. He states that "the essence of Spirit baptism" is "a baptism in divine love." (Macchia 2006, pp. 63-64). This divine love is not mere sentimentality but the expression of the Kingdom of God. Macchia ties Spirit baptism, the Kingdom, and love by declaring, "I am assuming throughout this book a Pentecost/Kingdom of God correlation. As a pneumatological concept, the Kingdom is inaugurated and fulfilled as a 'spirit baptism.' God's Kingdom is not an oppressive rule but the reign of divine love. Paul thus calls Pentecost an outpouring of divine love." (Macchia 2006, p. 17). He later says, "the highest description possible of the substance of Spirit baptism as an eschatological gift is that it functions as an outpouring of divine love." (Macchia 2006, p. 17).

This understanding, however, does not exclude or minimize the charismata in general or the Baptism in the Holy Spirit in the Pentecostal experience. On the contrary, Macchia warns against losing this or any other distinctiveness of Pentecostalism. He declares, "Pentecostalism has been blessed and gifted by God with certain theological and spiritual accents. We do other Christian families a disservice if we do not preserve and cherish these and seek to bless others with them. Thus, ideal would be a reworking of our distinctives in a way that cherishes our unique accents but expands them" in order to serve at the ecumenical table (Macchia 2006, p. 25).

Expanding on traditional Pentecostalism's use for the "Spirit baptism" experience (i.e., empowerment for ministry) (General Council of the Assemblies of God n.d.), Macchia specifies three additional benefits: (1) it provides a critique of the greater church's "lack of charismatic awareness and conscious participation in the diverse and vibrant witness of the Spirit" (Macchia 2006, p. 22); (2) the provision of ecumenical potential regarding which Macchia cautions, "too much stress on that which is distinctively Pentecostal can thwart the ecumenical vision", yet, "Spirit baptism has the greatest potential for connecting to other traditions toward the formation of an ecumenical pneumatology" (Macchia 2006, pp. $22,27)$; and (3) the baptism in the Spirit is a metaphor that is "descriptive of both God's action in inaugurating the Kingdom of God and our empowered witness to this Kingdom in the world." (Macchia 2006, p. 59).

According to Macchia, Spirit baptism and the Kingdom of God are intrinsically connected. As an example, Macchia points to Jesus' instructions to the disciples to go to the Upper Room. The instructions to wait for the Holy Spirit's baptism came in the context of teaching them about the Kingdom of God (Acts 1:3-6). Connecting the indwelling of the Spirit through Baptism and the Kingdom, Macchia states "the Son is the King and the Spirit is the Kingdom in the fulfillment of the Father's will." (Macchia 2006, p. 91). He thus makes the Kingdom synonymous with the indwelling of the Spirit in the believer (Macchia 2006, pp. 91-107).

Macchia develops his Spirit Baptism theology in light of the context of the eschatological coming of the kingdom of God, which will be the Divine indwelling of all creation and is the ultimate fulfilling of baptism in the Spirit (Macchia 2006, p. 103). The present workings of the charismata are therefore the "inauguration of the Kingdom of God that foreshadow the new creation to come." (Macchia 2006, p. 105). In the meantime, the Baptism "constitutes the church" and moves the church towards missions for the Kingdom. The movement towards missions is defined by a "holistic thrust" that is "personal, relational, and even political." (Macchia 2006, p. 106). The political thrust borne of the Baptism is reflective of and yearning for the Kingdom that is already within.

\subsection{Amos Yong}

In his book, The Spirit Poured Out on All Flesh, Amos Yong explores the opportunities that Pentecostal theology and practice bring for an ecumenical and global Christianity. 
He begins by warning against the dangers of a Kingdom perspective that focuses on the hereafter. Pointing to its societal effect and missed opportunities in early Pentecostalism in India and the US South he states, "among Dalit and poor whites in South, eschatological concerns took focus away from breaking caste and racial hierarchies (Yong 2005, pp. 56, 73). This comment sets the tone for Yong's analysis of Pentecostalism's social impact throughout the book. This is made evident when he speaks of the Kingdom of God.

Yong emphasizes that through the Holy Spirit's empowerment and the consequent realization of the Kingdom through signs and wonders, the Christians in the book of Acts and the Pentecostals in the early 20th century shared a sense of urgency in regard to the coming Kingdom. This, in turn, served as a missionary impetus. Through the charismata, the Spirit connects the coming Kingdom and the Kingdom that is awaited through the process of invitation into the Kingdom (Yong 2005, p. 83). This invitation is not limited to the impact that it has on individuals; it has a social impact. Yong states,

Healing as a communal experience is most evident in the case of cured lepers and demoniacs who were allowed to return to their homes and communities. In these instances, the Gospel healing accounts can be understood as processes of social transformation engaging the unbelieving community and breaking social taboos rather than merely in individualistic senses. Salvation is now understood in terms of 'hospitality': being reconstituted into the divine community, the new people of God. The needy are best able to appreciate the divine hospitality given through Jesus and the Spirit, and the saved them become instruments of divine hospitality heralding the eschatological kingdom.' (Yong 2005, p. 90)

Here, Yong introduces various important themes of a Pentecostal understanding of the Kingdom. He emphasizes the Spirit's impact on the community and its cultural or religious structures regarding their dealings with someone who had been heretofore marginalized from the community through the healing they had experienced. Through the power of the Spirit, someone who was not considered part of the Kingdom received wholeness. While there were healings that these individuals had to go through for their wholeness to become an existential part of their reality, the community itself, in its desire to obey God's commandments, had dehumanized itself by dehumanizing the leper and the demoniac to the point where the community needed healing. What the Apostle Paul said at one point is apropos here, "for the Kingdom of God is not a matter of eating or drinking, but of justice, peace and joy in the Holy Spirit" (Rom.14:17). Yong also emphasizes how it is the "needy" who are best able to "appreciate the divine hospitality", meaning the invitation and present expression of the Kingdom as well as what it must mean for the future. He states, "the Gospel also has an eschatological dimension that is both realized and future. The reign of God is not merely coming: "for in fact, the kingdom of God is among you' (Lk.17:21) ... The church lives betwixt and between; in the now and yet anticipating the not-yet." (Yong 2005, p. 90). In this sense, Yong espouses a "multidimensionality" of soteriological possibilities. In this perspective, salvation is historic and futurist, individualistic and communal (Yong 2005, p. 91). For Yong, the eschatological outpouring of the Spirit "indicates that eschatological salvation is experienced now and awaited." In what is a dramatic break from traditional Pentecostalism, he states, "thus salvation is both historical and directed toward the future transformation of all creation into the new heavens and new earth." (Yong 2005, p. 96). Rather than seeing the apocalyptic from a fundamentalist perspective, Yong suggests seeing the transformation as an affirmation of creation and God's desire to finally save and vindicate for those who "yearn for divine intervention" into their inescapable suffering due to a corrupt social order. Thus, the establishment of the Kingdom and the Spirit's working towards that end is a "critique and judgment of the present sociopolitical and historical order." (Yong 2005, pp. 96-97). In this manner, "the eschatological motif runs as a thread woven throughout the entirety of this Pentecostal theology instead of being set off as its own separate topic (or chapter) for discussion ... to individualize salvation is to arbitrarily abstract one dimension from a much more complex and complicated process of relationships." (Yong 2005, p. 97). 
These three scholars demonstrate a consistency in their respective Pentecostal theologies of the Kingdom that recognizes the importance of its imminence for the life of the Church. Although he does not elaborate on the implications for today, Gause effectively demonstrates the centrality of imminence throughout the Scriptures. Macchia and Yong's approach to the Kingdom can be seen as building on Gause's work. Their work exemplifies where Pentecostal theology of the Kingdom is (Macchia) and where it is going (Yong). While both speak of a social impact as a result of the Spirit's Kingdom activity, Macchia speaks of it as a result of an impact on individuals. Yong, on the other hand, speaks of a social salvation through the Spirit that operates through the Church but is not limited by the church's activity. In other words, the Kingdom goes beyond the church and so does its present moving. The stage is thus set to explore and locate US Latinx Pentecostal definitions of the Kingdom of God.

\section{A US Latinx Pentecostal Definition of the Kingdom of God}

In attempting to define a US Latinx Pentecostal theology of the Kingdom of God, I will use academic literature and non-academic literature that give voice to US Latinx scholars as well as practitioners. Given the formative stage in which US Latinx Pentecostal scholarship finds itself, there is not yet a distinct and comprehensive theology from a US Latinx Pentecostal perspective, making it difficult to arrive at a consensus theology of the Kingdom of God. Two Latinx Pentecostal texts that engage various theological themes are Samuel Solivan's The Spirit, Pathos and Liberation and Eldin Villafañe's The Liberating Spirit.

In The Spirit, Pathos and Liberation, Pentecostal theologian Samuel Solivan provides a foundational framework to develop a Latinx Pentecostal theology of orthopathos. That being his purpose, he does not provide a comprehensive analysis of the traditional theological categories that he addresses in the book. Likewise, Eldin Villafañe's The Liberating Spirit does not comprehensively develop the theological categories that come up in the text that are not directly linked to the Pentecostal social and ethical framework that he is developing. The absence of such a resource requires that an analysis of a theological category must be constructed on the basis of relevant, extant literature, which may emerge from variant genres.

The experiences of Latinxs in the US and in Latin America are distinct and should not be treated as one monolith. One of the key distinctions between US Latinxs and those in Latin America is the "minority" status of Latinxs in the US. Whether or not one is born in the US, Latinxs experience racial and class oppression as a result of the subordinate status that does not acknowledge full belonging and participation in US society. Another key difference is that Latinxs in the US are grouped as one community regardless of national origin. Whereas the people in Latin America identify primarily by nationality (e.g., Mejicano/a, Colombiano/a, Cubano/a) and base their political, economic, and social engagement on national or local situations, those distinctions are largely erased and replaced in the US for generalized terms such as Latinx or Hispanic. This is an imposed re-definition of identity created within the US context. It nevertheless creates shared experiences, struggles, and challenges among diverse Latinx communities.

\subsection{US Latinx Pentecostal Practitioners}

In the context of the larger Latinx US context, it is important to include the voices, not only of scholars, but also of those who have not had opportunities to obtain levels of formal education that can be described as exclusive. Including these voices is especially critical, since they represent where most of the US Latinx community remains in terms of its educational attainment. For decades now, the high school graduation rate for Latinxs has remained at a little over 50 percent nationwide (Traverso-Galarza 1997, p. 122). There remains, consequently, a tension in the process of identifying and defining the theology of a people given the great disparities in education attainment between US Latinx scholars and clergy. The disparity in education attainment is even more pronounced when we compare scholars and clergy with the Latinx community at large. 
How then can a theology be developed or uncovered that reflects the existential and epistemic reality of a people's faith? One way includes doing a significant amount of qualitative research that includes the voices of lay congregants in Pentecostal churches and the voices of establishment figures within US Latinx Pentecostalism. While the income and education levels of many well-known preachers or recording artists are not reflective of the community's reality, their popularity speaks to something that is resonating with the community. They are prophets in the Weberian sense in that they obtain their status by knowingly or unknowingly reflect, through the art of their preaching, what the people believe and live (Weber 1978, pp. 439-67). In such a discourse, popular voices of Latinx preachers and ministers in the Northeast US such as those of Rev. Leoncida (Mama Leo) Rosado, Rev. Jose Joaquin (Yiye) Avila, and Rev. Kittim Silva would have been included. These are pastors that have been influential in Latinx Pentecostal circles and have written extensively from a perspective that I would consider representative of the lived theology of three generations of Latinx Pentecostalism and in various ways have shaped Latino Pentecostalism in the Northeast US for their respective generations. Additionally, I would have included Dr. Jesse Miranda, who has dedicated much of his writings and work to practical ministerial development. In that context, he confronts the reality of a constantly changing Latinx population and the challenges that such a reality provides for the US Latinx Pentecostal church. Adding these voices to those included here would help to provide a more accurate representation of the US Latino Pentecostal church's theology. Unfortunately, the scope of this article does not permit us to do so. We do, however, have a representation that can begin a discourse on the US Latinx Pentecostal perspective on the Kingdom of God and its implication for the US Latinx community at large.

\subsubsection{Reies Lopez Tijerina}

Despite having only 6 months of formal education and only a partial Bible institute education as an adult, Reies Lopez Tijerina served as an itinerant Pentecostal preacher primarily in the Southwest and was a pastor with the Assemblies of God when he began his political engagement. His focus was on land grant justice for thousands of Mexican Americans in the Southwest who had their lands stolen by Anglo settlers. His legal research into the issue would eventually become the initial, legal framework for the Chicano movement. Tijerina's Valley of Peace community is the only known Latinx commune in US history. His militant activities included the takeover of Carson National Forest in 1966 (Tijerina claimed that the Forest was on property belonging to land grant holders) and the famous courthouse raid in Tierra Amarilla, New Mexico, where he went to make a citizen's arrest of the state District Attorney for his failure to prosecute settlers who had violated the land rights of Latinxs. It was particularly after the courthouse raid that Tijerina became a foundational figure in the Chicano movement and that the movement gained national visibility (Busto 2005, pp. 39-45). However, it was during his ministerial career that Tijerina was able to develop the oratory skills he would need to mobilize the Mexican American community into what would become the Chicano movement. More importantly, it was through his church ministry that Tijerina developed the framework of Kingdom justice that would underpin his life's political work. ${ }^{7}$

Spiritual formation in the Pentecostal church placed a great emphasis on the Scriptures and their literal interpretation (Busto 2005, p. 39). In terms of the priority of the Scriptures in the Latinx context, Francisco Garcia-Treto states, "Ingrained in every Hispanic Protestant's consciousness is the conviction that when a person or a people begins to read the Bible, change for the better follows (Garcia-Treto 1999, pp. 163-64). The number of references to "justice" in the Scriptures greatly impacted Tijerina, and he wanted to see the justice of God's Kingdom lived out somewhere because all he had seen since childhood was injustice prevailing. He wanted to see what Solivan describes as a "spirituality that incorporates elements of culture, religious experience and Christian tradition within the daily reality of struggle." (Solivan 1996, p.140). Tijerina had not been exposed to Bartolome de las Casas, Schleiermacher, or Rauschenbusch. Nor had James Cone's Black Theology and Black 
Power or Gustavo Gutierrez's A Theology of Liberation been published, so he did not find a theology that engaged the US Latinx socio-economic and political realities in the church establishment.

His sermons, collected in his book ¿Hallara Fe En La Tierra?, are a US Latinx Pentecostal theology of social justice that was not influenced or formed by academic or ecclesial institutions but by the experiences of oppression and by the Pentecostal church. His sermons reflect what he understood to be a Kingdom value of justice. For Tijerina, Scriptural passages of justice were affirmations that God is on the side of the oppressed and works on their behalf. His autochthonous Kingdom theology is very similar to what would later be known as Liberation Theology due to its themes of justice, God standing for the oppressed, and as Sobrino once said, "God being known through the poor." At one meeting of the New Mexico Board of Health and Human Services, Tijerina stated, "the poor will lead the rich into salvation, into enlightenment. Not with bullets, not with another war like Vietnam, but in compassion." (Busto 2005, p. 65). Busto's analysis of the longest sermon in ¿Hallara Fe En La Tierra? locates Tijerina's preaching in the Old Testament prophetic judgment tradition (Busto 2005, pp. 104-5). For Busto, this is important to understand, because it played a great role in Tijerina's political work and rejection. Tijerina's style of speaking to the people he was mobilizing or those whom he was castigating was the direct result of the no-nonsense, common-sense, fire-and-brimstone preaching that was characteristic of Latinx Pentecostalism up until the emergence of Prosperity Theology in the 1980s.

In the racially oppressive southwest of the 1950s, his holistic message and theology came with a price. In 1955, Tijerina and his congregation were locked out of their church by the Superintendent of the Assemblies of God who accused Tijerina of teaching unorthodox theology (Busto 2005, pp. 43,45). For Tijerina, it was ignoring injustice that was unorthodox. According to him, his message was against complacency, materialism, injustice, and the racial oppression by which he had been victimized since his childhood along with the Mexican American community in the Southwest (Busto 2005, pp. 44-45, 99-100). The clash with the Assemblies of God superintendent would be Tijerina's last formal connection with the Pentecostal church establishment (Oropeza 2019, pp. 36-39).

One cannot speak about Tijerina's religious understanding without also speaking about the role that miracles, visions, and dreams played in his epistemology. Tijerina claimed to have died and resurrected when he was about 4 years old. Hereafter, his uncles would occasionally refer to him as the "resurrected boy." (Busto 2005, p. 37). In 1956, Tijerina had a dream where he was taken by angelic figures to ancient cities and told he was chosen for a special purpose. This dream served as a clarion call that moved Tijerina in the direction of land grants justice for the people of the southwest (Busto 2005, pp. 122-31).

Tijerina did not have a positive view of the organized church, and this also impacted his political activity. Tijerina saw the church as complicit in the oppression of the Mexican American community and at the service of the empire. The Assemblies of God closed his church because he was preaching against complacency, racism, "pride, mercilessness, and materialism." (Busto 2005, p. 100). During his childhood, Tijerina saw his father change his faith from Catholicism to Protestantism because of fear of the protestant Texas Rangers who were notorious for their treatment of Catholics. In his memoir, They Called Me King Tiger, Tijerina states, "I know of no church in the Southwest that has risen in defense of our rights ..." (Tijerina 2000, p. 139). Protestant complicity was overwhelming in the New Mexico land theft of 1870 . The governor, who was a Methodist minister, ordered all of the Spanish land grants destroyed. Soon afterward, the Presbyterian church took land from the Mexican Americans (Tijerina 2000, pp. 28, 40).

Tijerina's life was one where the Kingdom broke through even in miraculous ways. The desire for the Kingdom life was so intense that it was almost palpable and led him to attempt to create a utopic community with many members of his former church. The Valle de Paz was intended to be a community where Christian love and values of the Kingdom were the only law. All the people had all things in common and worked together for the 
common good. His hunger for justice was such that when the systems were not serving the Mexican American community, he took what can be considered militant action. At Carson State Forest, Tijerina's organization, La Alianza, made passports and literally created an alternative community based on his perception of justice. The ideals of the Kingdom and Tijerina's desire for the reality of the Kingdom gave him the redeemed imagination of which Miguez Bonino will speak later in the paper.

\subsubsection{Piri Thomas}

Piri Thomas was not a member of the clergy but was a Pentecostal when he wrote his autobiography, Savior, Savior Hold my Hand. He converted to Pentecostalism after a life of drug addiction and spending time in and out of jail. After converting, he made a decision to dedicate his life working to help young people stay off the streets. What he says about the Kingdom in Savior, Savior is important because it expresses the understanding of the Kingdom from the perspective of a newly converted Latinx Pentecostal who was developing an organic ecclesiology through the lens of the streets of the inner-city.

At the beginning of the book, Thomas described a dialogue with his aunt who is Pentecostal and had just invited him to her church. His questions centered on theodicy in Spanish Harlem. He did not understand how a just God could allow the kind of suffering he saw all around him as a result of economic disparities. He was trying to determine whether or not the church was an escape or if it actually made believers stronger. Interactions with two Pentecostals gave him two different perspectives. An elderly man explained to him that the Kingdom was not of this world and that God's work would be done in the hereafter. In the meantime, the church served to help the Lord's people remain faithful. From this perspective, there was no place for the Kingdom in the present. When he asked his aunt, she described the present reality of the Kingdom without the theological language. "The church," she said, "binds much of us poor Puertoriqueños together. It gives us strength to live in these conditions. It's like being part of a familia that is together in Cristo and we help each other with the little materials we may possess." (Thomas 1972, pp. 19-21). In this apparently simple response, the Kingdom themes of community, mercy, and attending to "the least of these" are addressed.

Throughout his writings, Piri Thomas presented questions of the Kingdom as expressed through his concerns about racism in the Anglo church, the apathy of the church in the face of injustice, and whether or not God is present in the Ghetto (Thomas 1972, pp. 321-51, 358-60). An appreciation for his understanding of the Kingdom is obtained if one accepts his criticisms of the church as declarations of the Kingdom, even if negatively stated. Thomas believed that in the true church, there is no racism. In the true church, there is no apathy when it comes to injustice. The true church is present with the people of the Ghetto in their sufferings. Consequently, the true reflection of the Kingdom is not in the four walls of sanctuaries. Thomas stated, "to us people of the Barrio, the ghetto is our church, and the only way we're gonna make a heaven out of this hell is by getting together." (Thomas 1972, p. 360).

\subsubsection{Rev. Raymond Rivera}

Rev. Raymond Rivera's understanding of the Kingdom is reflected in the ministerial framework that he has developed. This framework includes the Four Principles of Holistic Ministry (Liberation, Healing, Community, and Transformation) and the Four Elements of Holistic Ministry (Conceptual, Contextual, Organic, and Incarnational) (Latino Pastoral Action Center n.d.). The Principles can be understood as guiding values of the Kingdom, whereas the Elements can be understood as characteristics thereof.

The Kingdom is a place of Liberation. This speaks to the reality of freedom within the Godhead and the Kingdom. Of his relationship with the Father, Jesus said, "I am in you and you are in me" (Jn.17:21). Nevertheless, his freedom to be, to desire, or to want was not compromised. Freedom within the Kingdom reaches out towards all Creation. Jesus' mission was "set captives free" (Lk.4:18) from the kingdom of darkness to the Kingdom of 
Light. Freedom is the condition under which humanity should live, because it has been created in the image of God. "Liberation" focuses on "liberation from social conditioning and systems". ${ }^{8}$ Anti-Kingdom systems and institutions are broken through the power of the Spirit.

The Kingdom is a place of Healing. God is a God of healing, as was expressed in the person of Christ_- "by His stripes we are healed" (Is.53:5). As do many evangelicals, Rivera interprets this passage as a prophecy concerning the Messiah. This perspective informs believers that whenever and however healing takes place, and no matter the kind of healing, it is a result of the Reign of God breaking into history through the power of the Spirit. For most Pentecostals, this Scripture is addressing spiritual and physical healing. Rivera's distinctiveness within a Pentecostal framework is that this passage also includes healing from mental, emotional, and social wounds. Social wounds in particular are caused by collectives of people and the social systems and structures they create. Systems and structures reflect the fallenness of humanity as understood in evangelical theology. For evangelicals, sin and the reciprocal wounding that results from it entered human nature after the disobedience of Adam and Eve, as described in the Biblical book of Genesis. While most evangelicals discuss sin in an almost exclusively individualistic way, Rivera focuses on the social repercussions of this theology.

For Rivera, this spiritual and social reality implies that God calls the community of faith to be a community of wounded healers as was the incarnated Christ; a healer of wounds beyond the Pentecostal understanding of the spiritual and beyond the physical but an understanding of healing that has social and political relevance and consequences. "Healing" also emphasizes the idea that in order for an individual to grow in their own healing process, he or she must grow to willingly and voluntarily draw from their past wounds and be a co-laborer in the healing process of others. In this case, one freely shares what one has experienced of the Kingdom. In its social application, this leads to communities of faith that develop ways to engage social problems based on their own experiences of oppression and marginalization. Rather than developing paternalistic models of ministry and community uplift, where the direction comes from disconnected or external institutions, community direction and ministries should emerge from the community itself.

The Kingdom is a place of Community. Although there are many non-Trinitarian Pentecostals, most are Trinitarian. For Rivera, God exists as a Trinitarian community: Father, Son, and Holy Spirit. As a result of humanity being created in God's image (Gen.1:27), God asks us to exist in community with God's own self and with others (Mk.12:33) in the Kingdom. Being a wounded healer, i.e., living a life that acknowledges the constancy of oppression and living a life of empathy with all who are suffering, inevitably helps the individual understand that they are a part of "Community". As communities of faith and the individuals therein practice being a "wounded healer", they grow in their sense of community. Community is a part of the Kingdom, as it reflects the image of God in the Church through the Spirit.

The Kingdom is a place of Transformation. Rivera teaches that God's description of the promise to restore humanity to its original purpose of being a community of love, i.e., the Kingdom of God, went through a trans-generational transformation process. The Kingdom promise began as the promise of a land (Gen.15:18-21) and ended as a promise of a city (Rev. 21:9-27). What did not change was its nature as a community of whole and loving relationships between all creation and God and humanity with each other. In a Barthian sense, all of God's creation is in a constant yearning and transformative movement to become the "not yet" from what it was and is into what will be. Growth is a constant in all of creation that demands transformation. In an evangelical sense, Rivera sees transformation in God's self-disclosure to humanity, how "in the fullness of time", that which "was not made known to other generations", the mystery of the Body, was revealed in and through Christ (Eph.3:1-13). For Rivera, God's self-disclosure will continue to transform, because context itself continuously changes and transforms. God 
asks individuals to go through a process of transformation by the renewal of the mind. Whatever form it takes, Holistic transformation leads to an increasingly divine communion between creation and the Creator. This principle encourages a continuous search for ongoing renewal of self, for one's neighbor, and in society. Being part of the Kingdom means acting as God would act on behalf of those who are excluded and exploited and whose voices are ignored.

Rivera defines the Elements of Holistic Ministry as Conceptual, Contextual, Organic, and Incarnational. This also describes the character of the Kingdom.

The Conceptual-Scriptures speak of various situations where God conceives of something before it is realized. For example, although there are various definitions of Predestination within Evangelicalism, most Christians would agree that the Christian Bible teaches that God pre-destined those who are to believe for salvation and chose them before the foundation of the world (Eph.1:4). The debate amongst evangelicals would be on the basis of that predestination. Another example of this would be that the believer is declared holy and perfect by God before it is an existential reality. These are examples of the conceptual in God as it relates to individuals. By faith, God's people are called to live guided by the conceptual that God deposits in us through various ways including the Scriptures, reason, tradition, and our experiences. Similarly, Rivera's framework, adopting from Barth, affirms that when the Church speaks of the Kingdom it also speaks of that which exists in the mind of God before it is fully realized, but it is already being realized in part primarily, but not exclusively, through communities of faith. The social implication of this element for communities of faith is that they ought to work towards a society that increasingly reflects the justice of the Kingdom now in the power of the Spirit. This understanding of the Kingdom is not explicitly expressed in any doctrinal statement of Latinx Pentecostal denominations. It is, however, the lived reality in many congregations as they serve their communities and goes against the stereotype of a Pentecostalism that is disconnected from social reality.

The Kingdom is Contextual because it exists and is interwoven within the history of creation. Rivera teaches that God has always used what the people knew in order to communicate with them. For him, the incarnation, i.e., the Christian teaching that Jesus was the incarnation of God, was the ultimate act of contextualization. God became man and "pitched his tent" among us (Jn.1:14). Contextualization continues in God's plan through the Spirit's work through the Church and outside of the Church proper. The Church's challenge, and what Rev. Rivera's ministry, the Latino Pastoral Action Center, attempts to do, is to contextualize itself within the Greater Heights community of the Bronx, NY. This happens by staying connected with the community through formal and informal means, learning about the conditions of the community from those who live there, and building leadership from within the community.

The Kingdom is Organic. There is a sense in which the manner in which the Kingdom reveals itself is consistent with its context without changing its essence. To explain this, Rivera speaks of "the incarnated Logos", Jesus Christ, who grew within and alongside a specific community and its own understanding of the world. While on earth, God completed a mission of dispensing all of Self, by teaching of the Kingdom that had arrived, by healing in order to demonstrate the power of the Kingdom, and unto death. All along, those who call upon the name of the Lord are invited to live an organic life and to bring others along for the journey. Today, the Holy Spirit continues to invite others to a life of organic growth through the Church. With this perspective, Rivera believes that Pentecostal congregations can develop ministries that are contextual and relevant to the needs and realities that communities face. This is in contrast to often well-funded outside organizations and ministries that assume to know the needs of a community without getting to know the community and its people.

The Kingdom is Incarnational. For Trinitarian Christians, the teaching of the incarnation is a central doctrine that speaks to a central aspect of the nature of God. To incarnate is to assume the form of a fleshly body, which Christians believe God did in Jesus Christ. 
However, the incarnation continues through the Church. As the Church is baptized in the Spirit, the Church is also baptized into the Body of Christ, thereby continuing the incarnation of Christ through the power of the Spirit. Rivera states that in the same way that Jesus's incarnation was accomplished by living among the people, Pentecostal churches set out to live among the people. He emphasizes that cultural notions of upward mobility, which means envisioning progress as leaving less-desirable neighborhoods for more desirable ones, ought to be re-evaluated. Instead, Pentecostal churches ought to pursue the transformation of the communities where they are located so that no one will want to leave. Thereby, in the same manner in which Jesus said, "the Kingdom of heaven is among you", the Church today says, "the Kingdom of heaven is among you."

\subsection{US Latinx Pentecostal in the Academy}

\subsubsection{Orlando Costas}

Costas was an evangelical missiologist who wrote prolifically during his short life. He challenged the Anglo evangelical church's racism and complicity in legitimizing US oppression in Latin America through its silence. Costas was able to impact the church through his missions-based emphasis on ecumenical theology and contextualization. One of his important contributions was to begin a dialogue with Latin American Liberation Theology at a time when most evangelicals dismissed it as "communism in sheep's clothing".

Although Costas was a Baptist, not Pentecostal, his influence on US Latinx Pentecostal scholarship cannot be understated. His openness to the charismata, focus on conversion, missionary zeal, and direct, no-nonsense challenges to the US church caused his life and work to resonate with US Latinx Pentecostals. He is one of the most often quoted among US Latinx Pentecostals scholars. His engagement with Latin American Liberation Theology allowed Costas to bring an evangelical form of Liberation Theology to US Latinx evangelicals when, for example, he lectured at Gordon-Conwell Theological Seminary in the 1970s.

Costas speaks significantly about the Kingdom of God in his text, Christ Outside the Gate: mission beyond Christendom, where he dedicates a section specifically this topic (Costas 1982, pp. 86-99). Costas describes the Church's missiological drive as eschatological in nature and part of the Spirit's function within the Church. The message of the church is the good news of the Kingdom of God. This is a message where liberation is immediate, based on Spirit-enabled conversion in which the believer becomes part of the Kingdom through the Church. Liberation is also progressive in relation to the degree to which the Church works towards the full realization of the eschatological Kingdom (Costas 1982, p. 90). Connecting the eschatological Kingdom with present reality, Costas states, "the final consummation of the Kingdom and that it is transcendentalized in the hope of new heavens and a new earth does not mean that this mission is atemporal or ahistorical. On the contrary, it is a mission whose stage is history." (Costas 1982, p. 40). It is at this point that Costas brings forth the relevance of the charismata to the Kingdom news: "the future hope of the poor is nourished by concrete signs: 'the blind see, the lame walk ... Those who own nothing in the world need not await the consummation of the Kingdom ... they can begin now to anticipate the Kingdom's transforming power. Because of its eschatological nature, the mission of God is historical." (Costas 1982, p. 91).

The people of God participate in the Kingdom through its contextual proclamation in word and deed, which must abide by the principles of "love, justice, freedom and messianic peace." (Costas 1982, pp. 91-92). The lived-out proclamation of the Kingdom principles imposes demands on the individuals that compose the Church as well as on the Church as a body. For the individual, it means abandoning an "individualistic and egocentric consciousness" and adopting one that is "communally and fraternally oriented." As for the social and institutional demands, the Church is called to proclaim and thus live out the Kingdom principles by being present "among the kingdoms of this world" by "limiting evil via political institutions" and by being part of the "hopeful groanings of creation." (Costas 1982, pp. 92-93). The Church, Costas urges, "needs to be present in the world 
to help transform it." (Costas 1982, p. 93). This "being present" includes participating through suffering in the groans of creation with the help of the Spirit. The Church suffers with creation as it unmasks and resists institutions that "become possessed of the devil and turn into enemies of justice." (Costas 1982, p. 93).

In this vein, Costas outlines specific priorities for the Church in the Americas. These include:

(1) Affirming life and denouncing violence-in the context of the 1970s, this meant denouncing US foreign policy that supported Latin American dictatorships. In the context of the Cold War, Costas also promoted socialist government systems in order to provide "genuine possibilities" for the poor in Latin America. Additionally, Costas called for the church's condemnation of state-sponsored kidnappings, torture, corrupt courts, and continued military build-up as part of a strategy of repression in various countries in Latin America.

(2) Human solidarity and Christian unity_ “"The division of peoples ... " Costas declares, "reflects the threat of death that besieges the human race ... These hemispheric divisions find their counterpart in the extraordinary divisions among Christians" (Costas 1982, p. 96-97). Given this reality, the Church is unable to serve as "agents of reconciliation among the peoples of the Americas." In order to right this wrong, Costas believes that the Church must pursue an ecumenical agenda.

(3) Commitment to evangelization and church growth-the evangelization that Costas refers to is being a witness in word and deed, working for the transformation of individuals as well as systems and structures of injustice. As Christians are formed or "made disciples" with this vision, the church growth that will occur will be a healthy church growth, not based on numbers but on a more holistic life in the Spirit (Costas 1982, pp. 97-98).

\subsubsection{David Traverso-Galarza}

It is only fitting that we now look at Pentecostal scholar David Traverso-Galarza's theology of the Kingdom, as he is a scholar of Orlando Costas and wrote his doctoral dissertation on Costas. In his article, Sin: a Hispanic Perspective, Traverso-Galarza indirectly presents a theology of the Kingdom of God as he develops a theology of sin and a theology of missions (Traverso-Galarza 1997). Regarding the overcoming of structural sin, he states, "what remains is to incarnate the signs of God's reign as we break down the walls of sin in our midst and restore life and dignity to the oppressed. This is a missional task that demands the power to challenge and to change: 'for the Kingdom of God does not consist in talk but in power.'" (Traverso-Galarza, p. 122) Although this is Traverso-Galarza's concluding statement, it reaches back and places the article in a context of eschatological hope. After providing a brief historic background of the theology of sin and of the history of colonization in Latin America, Traverso-Galarza presents what he calls "Orlando Costas' Radical Evangelical Approach" as an evangelical liberationist approach that will enable the church to address the socio-political and economic sinful oppressions in which the US Latino/a community find itself. This approach to sin addresses personal and social or systemic sin in that it asks an account of personal lifestyle, not in a vacuum but in relation to "sinful structures, systems, and institutions." (Traverso-Galarza, p. 120) The Radical Evangelical Approach means dealing with personal sin by dealing with the effects of sinful structures rather than ignoring them as does traditional evangelicalism and the doctrinal statements of most Pentecostal denominations. It means ministering to those who are oppressed by the systems, developing leadership from within those communities, and creating alternative institutions and systems. (Traverso-Galarza, pp. 120-21). Victories against personal and structural sin are obtained through the power of the Spirit, providing "signs of God's reign in our midst today." (Traverso-Galarza, p. 121). 


\subsubsection{Eldin Villafañe}

In his book, $\mathrm{Fe}$, Espiritualidad y Justicia, Villafañe outlines his theology of the Kingdom as part of a larger discussion on the church's engagement with principalities and powers (Villfañe 2006, pp. 62-64). It should be first be noted that "Kingdom", according to Villafañe, is first and foremost an act and secondarily a place, eschatological or otherwise. Therefore, we would be more correct to speak of the ruling or kingship of God rather than God's Kingdom as a location (Villfañe 1995, p. 23). As Sobrino reminds us, this distinction moves the reader away from thinking of a place and towards an action that is continuously occurring (Sobrino 2008, p. 78).

Villafañe believes that all divine activity in the history of humanity "is the action in and for the Reign of God." (Villafañe 2001, p. 23). In the life of Jesus, he points out that the Kingdom of God is the starting point and context of his mission (Villfañe 2006, p. 62). Through the power of the Spirit, Jesus is able to perform miracles that attest to the Kingdom as a present reality in his person and his works. According to Villafañe, Jesus lived and proclaimed a Kingdom justice that was personal and social. As it did in Jesus life, the Kingdom exists in the "now" and "not yet" (Villfañe 2006, p. 63). He states, "the message of the new Testament is that God's rule is already present in Jesus the Messiah, although it awaits final consummation in the not yet of the future." (Villfañe 2006, p. 184). The fact that Jesus sent his disciples in the manner that he was sent by God means that the church goes in the same power of the Spirit to its evangelistic mission of the proclamation of the Kingdom (Villfañe 1995, p. 24). The Acts 2 experience of Spirit baptism "was interpreted as a continuation of Jesus' mission in the power of the Spirit" and as the Joel 2 promise for the end times (Villafañe 1993, p. 186). The Spirit's presence is continuously confirmed with the eschatological Kingdom-interruption(s) of "signs and wonders."

Villafañe states that the "pouring" of the Spirit (i.e., manifestation of the charismata) brings together the community of the Kingdom for the purpose of making the Kingdom known in the present (Villfañe 2006, p. 64). Yet, while the church reflects the Kingdom, witnesses to its values, and is its most visible expression and its most "faithful interpreter", it is not the Kingdom." (Villafañe 1993, p.187). There is, nevertheless, a challenge for the church if it is indeed to be that which reflects and faithfully interprets the Kingdom. Villafañe calls for the Latinx Pentecostal church to move away from solely individualistic and/or solely futurist conceptualizations of the Kingdom to one that is also politically and socially engaged.

Regarding the role of the Latinx Pentecostal church, he states, "although the rule of Christ has not been fully manifested-awaiting the eschaton-his claim and dominion are to impact all human relations, meaning, the political process." (Villafañe 1993, p. 196). Furthermore, he states, "the Hispanic Pentecostal church must see itself not only as a locus for personal liberation, but also as a locus for social liberation." (Villafañe 1993, p. 201). Borrowing from Paul Lehman's language, Villafañe reminds Latinx Pentecostals that it is in society and its institutions where the "politics of the Spirit" takes place (Villafañe 2001, p. 25).

This engagement requires discernment of the Spirit's actions in the world, which includes understanding "the signs of the Reign present" within the community's resources that include culture, religious traditions, and social reality. Villafañe points to these as resources for Kingdom ethical reflection. Referring to cultural and socio-economic characteristics such as our "mestizaje", immigration experiences, and Catholic heritage, Villafañe encourages Latinx Pentecostals churches to "learn to see and affirm those signs of the Reign in its midst in the 'barrios' if it is to discern those signs outside." (Villafañe 1993, p. 198). The Spirit's work is not only to convict of sin, justice, and judgment but also to restrain and to help. This is what we see wherever we see "goodness, love, peace, and justice exercised in God's creation-genuine sighs and signs of the Reign of God." (Villafañe 2001, p. 26). This is particularly emboldening for a church that emphasizes the power of the Spirit being available in today's context. He concludes, 
The baptism of the Spirit in Hispanic Pentecostalism is rightfully seen as empowerment for service, impacting the believer deeply-giving him/her tremendous boldness, a heightened sense of personal holiness, a new sense of self-worth and personal power. Yet, the narrow individualistic focus and purpose implies the dissipation in the "culto", if not elsewhere, of so much energy-spiritual power-that can and should be "tapped" for the broader missional objective of the church. The Hispanic Pentecostal church has the spiritual resources to face the spiritual power encounters of our social struggles. (Villafañe 1993, p. 204)

\subsubsection{Samuel Solivan}

Although the development of a Kingdom Theology is not the focus of Samuel Solivan's book, The Spirit, Pathos and Liberation, it provides a needed perspective about Kingdom Theology as he unpacks his epistemological notion of orthopathos, or right passion/feeling/ emotion. In this endeavor, some liberty has been taken on my part to assume that his explicit statements relating to pneumatology and Kingdom theology are conceptually and practically consistent throughout his writings, and I will thus draw possible Kingdom theology implications. This assumption is not entirely without basis, as Solivan states that "any claim or understanding of orthopathos should find some correspondence in God's self-disclosure to us." (Solivan 1998, p. 38). Macchia's Spirit baptism theology would affirm that Spirit baptism is indeed God's self-disclosure of love that is coexistent with the Kingdom. Therefore, as Spirit baptism is inseparable from the "not-yet" Kingdom, orthopathos can also be said to be inseparable from the "not-yet" Kingdom. Just as the present reality of the Kingdom is divine love, orthopathos is also divine love. According to Solivan, God's orthopathos is the ontological relation between God and humanity and is "circumscribed by God's love, righteousness, justice and holiness." (Solivan 1998, p. 38). If the church is that institution that Villafañe says reflects the Kingdom, witnesses to its values, is its most visible expression, and is its most "faithful interpreter", then the Church is called to live the orthopathos of that Kingdom, the orthopathos of God, (Solivan 1998, p. 60) or, as Sobrino put it, "God's way of acting ... should be Israel's way of acting." (Sobrino 2008, p. 78).

The Church's present expression of the Kingdom is commensurate with God's orthopathy; it is also commensurate with God's diversity. In his article, The Holy Spirit: a Pentecostal perspective, Solivan makes the case that Pentecost created an opportunity for reconciliation among diverse communities, thus "reflecting the nature and the content of the Kingdom of God." (Solivan 1997, p. 56). The Holy Spirit leads and empowers the Church to fulfill this purpose without the deceptive need for homogeneity (Solivan 1997, p. 57). Solivan speaks of an embrace, not mere tolerance, of diversity as the ethic of love. The decision to assume this "Spirit-led" responsibility is a call "to incarnate the Kingdom of God (Solivan 1997, p. 63). Solivan defines this possibility as something that can only be obtained through the power of the Spirit, declaring, "diversity and inclusivity are a sign of the reign of God and the presence of the Holy Spirit among his people. Pentecost was another sign of the inbreaking reign of God. The outpouring of the Spirit was and continues to be a precondition for the possibility of diversity in the church today." He continues with a poignant statement, "neglect of this aspect ... has contributed to an understanding of the Spirit's fullness that does not require that we love one another." (Solivan 1997, p. 62).

According to Solivan, the sources for Latinx Pentecostal theology reflect Kingdom principles and values, as they are the product of a marginalized community that is led by the Spirit. The first source is Latinx spirituality. By this, Solivan refers primarily to the weekly culto where "spirituality finds its center and clearest expression ... The worship service is the place and the occasion where the sources and the norms that inform our theology come together." (Solivan 1996, p. 140). Here is where the Kingdom is most fully expressed. Additionally, Orthopathos makes the way for the worlds of passion and reason to converge here and engage in a dialectic for worldview development that critiques the inconsistencies and injustices of modern society. The second source is the personal and 
communal experience (Solivan 1996, p. 142). Conversion and spirit Baptism are experienced in such ways that, although very intimate and personal, are shared and celebrated in the community. The third source is the Scriptures. Dependence on the Scriptures is not based on a propositional ascent but on the "submodern consciousness" of a suffering community that has been visited by the Spirit (Solivan 1996, p. 137). This enables the community to grow in their faith as an expectation of Kingdom intervention heightens. The final source that Solivan mentions is proclamation found in preaching, pastoring, and teaching. Through these opportunities, the Spirit prepares, equips, and empowers laity who might otherwise never have an opportunity at leadership (Solivan 1996, pp. 140-46).

What does a US Latino Pentecostal perspective teach us about the Kingdom of God? A Pentecostal perspective makes space for an "openness" to the Spirit's breakthrough of the eschatological Kingdom in the present through miracles, dreams, and the supernatural. A dream that Tijerina had prior to beginning his political activity is what carried him through his most difficult times and enabled him to continue doing his work despite arrests and even the largest manhunt by the military within US borders. Thomas's aunt spoke about the power of the Pentecostal church to deal with the reality of death that surrounded Spanish Harlem.

A consistent theme in all practitioners and scholars discussed is a conflictive relationship with the status quo. There is a questioning, because things are not how they should be. Both Tijerina and Thomas bring critical questions to the church itself. While Costas, Traverso, Solivan, and Villafañe all state that the church is the most visible expression of the Kingdom, both Thomas and Tijerina question where that expression can be found. Thomas ends Savior, Savior Hold My Hand telling his wife that he finds it in the struggle for survival in the community of the barrio. Tijerina's life shows that he found it in his revolutionary community. Through their activism, both participated in the Reign of God. This begs the question of whether or not there is always an expression of the Kingdom in the church. Thomas attended an Anglo church and was met with classism and racism. However, when he observed his storefront Pentecostal church, he saw an escapist religion. If he looked closer, however, he may have seen that the church was indeed an expression of God's Kingdom, but he was looking through the lens of traditional activism rather than through the lens of an intuitive spirituality from the people that indeed sustained and empowered them. Tijerina, it seems, experienced too much pain in the church and left, never to return. During his years in the church and during his years of political activism, he experienced personal and structural racism. Eventually, he came to see the role of religion in the oppression of the Mexican American community as irreconcilable with Kingdom values.

Rivera, Traverso, Villafañe, and Solivan seem not to have these questions. They have resolved that the Spirit and the Kingdom exist in the Church. The Kingdom of God is greater than the church, but the church is nevertheless instrumental in making the Kingdom present during the "not yet." This should not be interpreted to mean that these scholars have not suffered or experienced racism or oppression within ecclesial institutions or the theological academy. It does mean, however, that they have come to terms with those tensions and affirm a Kingdom presence within religious institutions despite their imperfections. Pentecostals believe that through the "sealing of the Spirit", Christians have been assured salvation until the day of Redemption (Lk. 24:49, Eph.1:13-14, 4:30, II Cor.1:21, 22). For these scholars, the "eschatological presence" of the Holy Spirit in the believer ensures that the future described in that vision is the starting point for the believer's life because of the hope in the resurrection and life eternal and a fully manifested Kingdom of God with all of its implications that will be effectuated through the power of the Spirit (Rom.8:11) (Barth 1997, pp. 59-60). Because, for them, the end has already been ensured, i.e., because God has said the Kingdom will be fully actualized at a future point, these Pentecostal scholars urge their churches to confront systems and structures of injustice boldly and in the power of the Spirit towards that end in the here and now. 


\section{Latin American Liberation Theology and the Kingdom of God}

In their text, Introducing Liberation Theology, Leonardo and Clodovis Boff describe their hermeneutical approach in what they call three "mediations" i.e., socio-analytical, hermeneutical, and practical (Boff and Boff 2004). The socio-analytical mediation "tries to find why the oppressed are oppressed" and uses actual analytic tools such as Marxism in order to be informed of actual conditions (Boff and Boff 2004, pp. 24-28). The hermeneutical mediation brings to the forefront a theological-political reading of the Scriptures that is performed on the basis of the poor and favors application rather than liberation (Boff and Boff 2004, pp. 33-39). The practical mediation takes place in action (Boff and Boff 2004, pp. 39-40). The Bible is the central text. All Scripture is read in a "Christological key, that is, based on the high point of revelation found in the Gospels. The viewpoint of the poor is thus placed within a wider viewpoint, that of the Lord of history, whence the word of God derives its consistency." (Boff and Boff 2004, p. 35). Liberation Theology (LT) speaks about the present reality of the Kingdom extensively. Most LA Liberation Theologians steer clear of making final declarations about the Kingdom. The experience of colonialism has taught Liberation Theologians that, although the church is called to work for the establishment of the Kingdom, the church would claim its authority to usher in a new Kingdom at its own peril. Such a privilege belongs only to God.

\subsection{Clodovis and Leonardo Boff}

Boff identifies the Kingdom as one of the central topics of Liberation Theology (Boff and Boff 2004, p. 52). He says that "no other theological or biblical concept is as close to the ideal of integral liberation as this concept of the Kingdom of God." (Boff and Boff 2004, p. 52). Boff states that Liberation and the Kingdom are alike in that they both speak of an individual and social salvation that is holistic (Boff and Boff 2004, p. 91). It is in our midst and while not of this world, "it nevertheless begins to come about in this world." (Boff and Boff 2004, p. 52). The Kingdom is incarnated in historical liberations, which are necessary because of the effect of sin. Therefore, we understand the Kingdom not as a futuristic notion to be hoped for, but something made concrete in Jesus' actions.

Jesus' actions and thus the present reality of the Kingdom can be seen in the action of the Spirit in bringing forth the base Christian communities (Boff and Boff 2004, p. 56). As believers engage in building the "human city" through the base Christian communities, suffering persecution and martyrdom, they are demonstrating that they are already members of the Kingdom and that they are building the eschatological city of God (Boff and Boff 2004, p. 63). Therefore, the evangelist will not grow weary in their historical hopes, because these are tied to eschatological hopes (Boff and Boff 2004, p. 94). If people are filled with faith and passion for the Gospel and are hungry and thirsty for justice to the extent that they create the human predispositions and material conditions for it, only then can the Kingdom be established on earth.

\subsection{Gustavo Gutierrez}

In his work, A Theology of Liberation, Gutierrez suggests, "this opening of eschatology to the future is inseparably joined with its historical contemporaneity and urgency" and has "clear and strong implications for the political sphere, for social praxis." (Gutierrez $1973,122)$. With the vision of the coming Kingdom in mind, the Church works towards continuously bettering society (Boff and Boff 2004, pp. 92-93). The manner in which the Kingdom is realized differs among theologians. Gutierrez supposes that it is humanity that will essentially make the Kingdom a reality; it is "something to be achieved." (Gutierrez 1973, p. 135). However, these statements speak to a prophetic and redeemed imagination that is to be possessed by the Church in every sphere of life so that it may express the Kingdom in the "now." This Kingdom imagination expresses itself in a variety of ways to address the multifarious needs in oppressed communities.

Despite the diversity of callings and gifts provided by the Spirit to effectuate the calling Gutierrez states, "the kingdom of God provides the unity; the church and the world, 
each in its own way, contribute to its edification (Gutierrez 1973, p. 37). For Jesus the Kingdom was, in the first place, a gift. Only on this basis can we understand the meaning of active human participation in its coming; the Zealots tended to see it rather as the fruit of their own efforts." (Gutierrez 1973, p. 132). "Blessed are the poor", not because poverty is romanticized by Liberation Theologians (or by Jesus, for that matter), but because it means that God is certainly working on their behalf (Gutierrez 1973, pp. 170-72).

\subsection{Jon Sobrino}

In both texts, No Salvation Outside the Poor and Jesus the Liberator, Jon Sobrino makes the case that the Kingdom is for the poor. He goes further and says that there is no salvation outside the poor. Like Villafañe and Solivan, Sobrino prefers to use the term "reign of God" as opposed to "Kingdom of God" to emphasize God's continuous activity and action for liberation. Sobrino reminds us that beginning with the people of Israel, the reign of God was always experienced in concrete ways with historical dimensions for the purpose of transforming "unjust socio-historic reality into one that is just." (Sobrino 2008, p. 71). This Kingdom "also becomes a task for the people of God," the elect, because the Church's mission calls it to act as God acts (Sobrino 2008, pp. 78-79).

In order to act in a manner consistent with the Kingdom, the values of goodness, compassion, justice, and reconciliation with God must be reproduced. These are signs of the "imminent arrival" of the Kingdom that maintain hope in oppressive contexts. Sobrino tells us that these signs are lived out personally. There are requirements that are asked of the individual, such as following Jesus, acting out the reign, molding the self according to the message and person of Jesus, sharing in his sufferings, and relating to God as a personal reality (Sobrino 2008, pp. 79, 96). Sobrino states that this is a life that brings hope "above all to the poor."

Utopia, the fully realized Kingdom, is a specific place to which we have but a shadow of understanding at the moment. In this vein, Sobrino states, "knowledge of the final reality, of the Kingdom, belongs to God alone." (Sobrino 1993, p. 69). The signs of the Kingdom as reflected in the lived values of the Kingdom bring hope, because they testify to an extant place (Sobrino 2008, p. 81). This extant place, which is partially seen in the present, is challenged with what Sobrino calls the "anti-Kingdom." (Sobrino 2008, p. 83). Sobrino advises that the poor can struggle against the anti-kingdom through social organizations and grassroots movements that expose the anti-kingdom for what it is. This requires not only knowing and analyzing the death warrant of the anti-kingdom but also action. That action is costly, Sobrino warns, but it is the Spirit that will enable the Christian to follow Jesus (Sobrino 2008, pp. 84-91).

Jesus' own understanding of the Kingdom is important for those who desire to participate in its present reality. Sobrino highlights the following of Jesus' concept of the Kingdom: (1) the Kingdom of God is at hand, (2) it is God's initiative and grace, and (3) the Kingdom is good news because "God is coming close because God is good." (Sobrino 1993, pp. 70-79). The reality of God's goodness is demonstrated in Jesus' works of miracles and his casting out of demons. These were the evidence of the Kingdom, especially for the poor and marginalized (Sobrino 1993, pp. 88-99).

\subsection{Jose Miguez Bonino}

In Doing Theology in a Revolutionary Situation, Jose Miguez Bonino counters the notion of a mystical Kingdom as coming from Hellenic ideas (Bonino 1975, p. 133). He believes that God's action is a constant call to humanity to participate in the building of the Kingdom, which occurs in history, and that the Church is called to undo the effects of Hellenic influences (Bonino 1975, pp. 138-39). The consequence of this acceptance has been the separation of the eschatological from the historical, resulting in the inability of the Kingdom to redeem, transform, and perfect society. Rather than thinking of the Kingdom as a place, the Kingdom ought to be understood as the action of the church, a mission to be fulfilled 
(Bonino 1975, pp. 141-43). There is, therefore, a deep relation between political and social action and God's eschatological Kingdom.

Bonino encourages the Church to enter the historical narrative in action for God's redemptive purpose of the Kingdom. This action is a witness of judgment for the systems, as it exposes structural and systemic choices for evil that are being made. The engagement must be an informed one that takes into account "new human possibilities" that would help us understand how to "enlarge our understanding of the biblical witness." (Bonino 1975, pp. 150-51). This in turn will awaken a redeemed, liberatory imagination for the Kingdom. This imagination is not utopian, wishful thinking but is based on the demonstration of the Kingdom in history and the possibilities that it awakens in us. The faith-inspired imagination thinks of the "not yet", based on the "now." Bonino concludes, "an eschatological faith makes it possible for the Christian to invest his life historically in the building of a temporary and imperfect order with the certainty that neither he nor his effort is meaningless of lost." (Bonino 1975, p. 152).

\section{Evaluating Kingdom Theology and Praxis}

Pentecostal Liberationists-In describing the reality of the Kingdom Pentecostal Liberation, Ethicist and Theologian Eldin Villafañe takes a literalist approach. He states that "while we live in the not yet of complete fulfillment of the Reign that awaits the parousia, we nevertheless continue to share in Jesus' mission of liberation through proclamation and demonstration." (Villafañe 2001, pp. 23-26). Yet, even this possibly irreconcilable point of divergence with theology that is considered more critical is not significantly different from what Leonardo and Clodovis Boff assert,

The Holy City, the New Jerusalem that comes down from heaven (Rev.21:2) can be established on earth only when men and women filled with faith and passion for the Gospel, united with each other, and hungry and thirsty for justice, create human dispositions and material conditions for it. But the earth will not then be the same earth ... The new earth will be a gift of God. (Boff and Boff 2004, p. 95)

The commonality among non-Pentecostal Liberation theologians is the embrace of a breaking through of the eschaton into present reality, specifically through the struggle for liberation. Pentecostals will agree with part of the Boff brother's assertion above ("the earth will not then be the same ... the new earth will be a gift of God"). Pentecostal eschatology is strictly literalist, dispensationalist, and pre-millennial. In the context of World Wars and the Cold War in which US Pentecostalism emerged, it is no surprise that its eschatology played a significant role in its growth. The idea that "no one knows the day nor the hour" of the Second Coming certainly drew followers, but the sense of urgency, combined with other historical factors, also caused Pentecostals to withdraw from social engagement. The eschatological perspective brought forth by these Pentecostal scholars, however, shows that engagement with present-day social problems is not only consistent with Pentecostal eschatology but that perceiving Kingdom theology as they propose demands it.

\section{The Kingdom in Practice in US Latino Pentecostalism}

The US Latinx community is very religious and Christian. Despite the growth of the religiously unaffiliated in the US among all racial and ethnic groups including Latinxs, (Espinosa et al. 2005) says that 93 percent of US Latinxs identify as Christian. Of them, Villafañe states, "there is no area of life, no matter how trivial, that is not 'transmuted' by the religious sentiment." (Villafañe 1993, p. 41). Therefore, when we speak of Kingdom responses to oppression, it is difficult to make clear distinctions between what is traditionally identified as secular and sacred. These two are inextricably intertwined in the Latinx social and historical context. In this section, I will focus on the actions and events of US Latinx Pentecostal clergy and clergy mobilization that point to an intuitive social engagement while generally promoting a theology of individual salvation and detachment from "this world" that simply awaits the parousia. 
Any aspect of US Latino history must seriously take into account the historical expansionist agenda of the United States. In 1835-36, the Texas-Mexico War ended with Texas becoming a Republic and soon thereafter being annexed by the US in 1845 . Soon thereafter, two major events defined the boundaries of the United States and have greatly affected the relationship of the United States and the Latinx community within it: first, the 1846-48 US-Mexico War. The Treaty of Guadalupe Hidalgo, which effectively ended the war, resulted in the loss of the Southwest region to the US, and second, the Spanish American War, which ended in 1898 and, in effect, made Puerto Rico a US colony.

Within Mexico, the Mexican Revolution (1910-1917) contributed to large migrations to the US including that of Mexican priests and nuns. This helped alleviate the shortage of Latinx clergy for a time. Over one million Mexicans immigrated during and after the Mexican Revolution.

The first and most obvious form of resistance was militant in form. It was seen first in the 1847 Taos Revolt in the Southwest. In 1889-91, the Gorras Blancas raids in New Mexico were an attempt to discourage Anglo settlement. In 1915-16, the San Diego raids at the Texas border were attempts to overthrow the newly established US rule (Crespo 2003, p. 150). In 1922, the Puerto Rican Nationalist Party was established with a militant agenda for the independence of the island colony of Puerto Rico. There were many confrontations between law enforcement and the Party on the island, but in 1954, Puerto Rican Nationalists attacked the US House of Representatives (Denis 2015, pp. 185-208). As will be discussed below, the most brazen actions of anti-colonial resistance took place in 1966 when Pentecostal pastor Reies Lopez Tijerina, along with the Alianza Federal de Mercedes Rosales, reclaimed 500,000 acres and occupied the Echo Amphitheater campground in New Mexico. He followed this with another action in 1967 when Tijerina raided a courthouse in order to arrest the state attorney general and call for justice in land grant cases.

\section{The Kingdom Confronting Oppression}

\subsection{Gender Oppression}

It is in the context of the US-Mexico War, the Mexican Revolution, and the Spanish American War, and their surrounding events and impacts that what came to be known as the Azusa Street Revival took place. From 1906-1909, the Pentecostal movement began under the leadership of African American Pastor William J. Seymour. Sanchez-Walsh correctly warns against idealizing the Revival. The Azusa Street Revival was not, as it is often described, the racially harmonious historical moment where gender did not play a role (Sanchez-Walsh 2003, pp. 1-47). Yet, despite its shortcomings, the gathering of people of color and whites, as well as the influence of women, was controversial enough to draw the attention of the media and was seen by some as pointing towards an eschatological direction. The Movement itself can be defined as a Kingdom expression of resistance to a racist and increasingly professionalized church in the US. Pentecostalism created spaces of expression and self-determination for communities that were marginalized and for women of all races. One of the first women to emerge as a leader is Romana Carbajal de Valenzuela. In 1914, Romanita Carbajal (as she was affectionately known) went to Mexico and established three Oneness Pentecostal denominations, including Iglesia Apostólica de la Fe, La Luz del Mundo, and Consejo Espiritual Mexicano. ${ }^{9}$ In 1915, Alice Luce along with HC Ball and Rodolfo Orozco co-founded the Latin District Council of the Assemblies of God, which was the first Latinx district in the Assemblies of God (Espinosa 1999, p. 599). While Luce is not Latinx, her role in the establishment of the District and the first Latinx Bible institute, the Latin American Bible Institute (LABI), is honored to this day. Aimee Semple McPherson's ministry was also well received in the Latinx Pentecostal community. In 1927, Aimee Semple McPherson began the Foursquare Church Spanish ministry. In 1935, another woman would establish a denomination. The Rev. Leoncia Rosado Rousseau (affectionately known as "Mama Leo") arrived in NYC and founded the Damascus Pentecostal Christian Church (Machado 2006, p. 269). 
Latinas brought with them a progressive social vision. In 1942, Juana Garcia Peraza established the "Mita" mega-church in PR. Today, many Pentecostals consider the church a cult, but before those issues emerged, and even afterward, the church was engaged in an extensive social outreach ministry agenda. In 1957, Mama Leo founded the Pentecostal Damascus Youth Crusade in the Bronx, NY, as an outreach to addicts in New York City. In 1969, a graduate of Mama Leo's Damascus Youth Crusade, the Rev. Ana Villafañe, established Way Out Ministries in the South Bronx to provide faith-based drug rehabilitation and recovery. ${ }^{10}$ In 1982, Rev. Aimee Garcia Cortese founded Crossroads Tabernacle as a bi-lingual Pentecostal church at storefront location in Bronx to minister to second- and third-generation Latinxs but also to other racial and ethnic communities. Crossroads became one of the first multi-ethnic, multi-racial, multi-cultural congregations in the United States in its membership and leadership. Prior to starting the church, Cortese was pressured to leave the Spanish Eastern District of the Assemblies of God. Crossroads Tabernacle eventually grew to over 2000 members and continues to be a vibrant church in New York City today. In 1986, Pentecostal minister Rev. Rosa Caraballo established Bruised Reed Ministries for families impacted by HIV / AIDS (Espinosa et al. 2005, p.208). Because it had been identified only 5 years earlier, there were still a lot of myths about HIV / AIDS, making her work all the more a true and courageous witness of Kingdom values. In 2003, Bruised Reed Ministries partnered with Esperanza US and became a national program. ${ }^{11}$ In the case of early US Latinx Pentecostalism, the Kingdom challenged notions of patriarchy and through that challenge provided a legacy of denominations, education institutions, and ministry to communities that were marginalized even within already marginalized communities.

The level of resistance to the leadership of women in ministry cannot be understated. Despite Pentecostalism's history of women who brought about significant change, doctrinal openness to the ministry of women, the increase in the number of women being credentialed as ordained ministers within those denominations, and women being the majority of membership in churches, their representation in the middle and highest levels of denominational leadership is not close to being proportional to the membership of those denominations or churches. Rarely are their names presented for candidacy in the most influential and large churches when positions for ministry open. Despite these challenges, Pentecostal women have found ways to make lasting impacts within Pentecostalism that reflect their understanding of Kingdom priorities in society.

\subsection{Religious Oppression}

Another way in which the Kingdom has been evident in US Latinx Pentecostalism is through autochthonous institutions such as denominations that serve as alternatives communities to those that have been beset by racism and colonialist notions in their practices, theology, and leadership. We have already mentioned Romana Carbajal de Valenzuela, who founded three oneness Pentecostal denominations in Mexico, and Alice Luce and Rodolfo Orrosco founding the first Latinx district of the Assemblies of God. In 1916, Francisco Llorente and Antonio Castadeña founded the Oneness Apostolic Assembly of the Faith in Christ Jesus (Espinosa 1999, p. 599). That same year, Juan Lugo was ordained by the Assemblies of God and established at least 16 churches throughout Puerto Rico in the next 14 years (Villafañe 1993, pp. 92-93). Unfortunately, less than 15 years after the Azusa Street Revival, a revival that despite its racial struggles brought together people from different races, languages, and backgrounds, racism would once again play a role in a division of the Pentecostal church.

In 1923, Francisco Olazabal and other disenchanted ministers left the Assemblies of God due to racism. A Moody Bible Institute graduate, Olazabal was the better-qualified candidate and had the favor of the pastors to become the first elected superintendent of the Latin District of the Assemblies of God. Under unclear circumstances, denominational leadership made a maneuver that effectively stopped any voting for the position, keeping Ball and Luce in charge of the nascent District. Interpreting what happened as racism, 
Olazabal left with almost half of the other churches in the district and established the Concilio Latinoamericano de Iglesias Cristianas (Villafañe 1993, pp. 90-91). In 1937, Concilio Latinoamericano established its 150th church under Olazabal's leadership. With over 50,000 members, the Concilio was the largest Latino denomination among all Protestant denominations and the fourth largest Pentecostal denomination (Villafañe 1993, pp. 90-91). In 1939, Concilio Latinoamericano divided shortly after Olazabal's tragic death and Asamblea de Iglesias Cristianas, and soon thereafter, at least four other Latinx denominations were founded (Villafañe 1993, p. 612).

The Latinx Pentecostal church continued to grow at unprecedented rates. By 1953, 75 percent of Protestant, Latino churches in NYC were Pentecostal (Villafañe 1993, p. 99). In 1957, the Distrito Hispano del Este de las Asambleas de Dios (Spanish Eastern District) was established and eventually established three of the Assemblies of God Latinx districts. These Latinx concilios have provided alternative organizational structures of religious communities that have been self-sustaining and have provided means for selfidentification to communities under oppression.

The story of RadioVision Cristiana is worth mentioning here because, although it is a Christian radio station and not a denomination, it has as much influence as, if not more influence than, many Latinx denominations in the New York, New Jersey, and Connecticut tri-state area, particularly as it relates to social issues. RadioVision began in Patterson, NJ, and has grown to be a significant hemispheric media entity built primarily on the support of the community and Latinx denominations. RadioVision Cristiana has always been supported and sustained primarily by the Latinx Pentecostal church members, congregations, and denominations in the Northeast US.

In 1983, RadioVision Cristiana began as Radio Hispana Evangélica by five pastors from the New York City area with 5 hours of programming per week ${ }^{12}$ Shortly thereafter, the group renamed its broadcast RadioVision, began 24-h Christian, Spanish broadcasting, and cast a vision for its listening audience of station ownership. Five years later, the purchase of RadioVision Cristiana was finalized for $\$ 22$ million with the support of denominations but primarily with the support of individual donors. ${ }^{13}$ In 1993, RadioVision Cristiana began broadcasting in the Caribbean ${ }^{14}$, and in 1997, the board approved the purchase of a radio station in the Dominican Republic and began transmitting from the Caribbean to South America. ${ }^{15}$ In 2001, RadioVision purchased a third broadcast station in Quito, Ecuador, and is now accessible in most of Latin America. ${ }^{16}$

\subsection{Educational/Ideological Oppression}

Kingdom activism has a long tradition when it comes to the establishment of educational institutions. In 1926, the Latin American Bible Institute (LABI) was established in California (Sanchez-Walsh 2000). LABI continues to operate today and is also a college of the Assemblies of God. In 1935, Juan Lugo established the first Latinx Bible Institute in NYC (Villafañe 1993, p. 94). Two years later, he went to Puerto Rico and established the Instituto Bíblico Mizpa. ${ }^{17}$ The multiplication of Bible institutes has continued ever since. Elizabeth Conde Frazier points out that today, over 80 percent of all Latinx pastors receive their ministerial training in Bible institutes (Conde-Frazier 2005).

Beginning in 1976, US Latinx Pentecostalism began to focus on the accessibility of higher education to Latinx ministers. Two particular initiatives were headed by scholars with Pentecostal roots, and while the initiatives did not specifically target Latinx Pentecostals, they have resulted in benefiting the US Latinx Pentecostal community. In 1976, the Center for Urban Ministerial Education (CUME) was founded by Assemblies of God Minister, Rev. Dr. Eldin Villafañe, with the Gordon-Conwell Theological Seminary to provide theological and ministerial training for ministers serving in urban contexts. This was the first seminary to offer accredited courses offered in Spanish (Villafañe et al. 2002). In the 1980s, Rev. Dr. Benjamin Alicea-Lugo, UTS alumni and grandson of Rev. Juan Lugo of the Fund for Theological Education, commissioned Dr. Justo L. Gonzales to study Hispanic Theological Education. The result of this study would lead to a Pew grant that 
funded the Hispanic Theological Initiative (HTI) and the Hispanic Summer Program (HSP) (HTI was initially directed by Rev. Dr. Daisy Machado. The HSP is currently led by her. Although now ordained with the Christian Church-Disciples of Christ, Machado grew up in the Latinx Pentecostal church). ${ }^{18}$

In 1981, the Iglesia de Dios Pentecostal Misión Internacional (MI) established the Seminario Pentecostal de Puerto Rico for undergraduate theological education. Additionally, MI renamed the Instituto Bíblico Mizpa Colegio Pentecostal Mizpa to reflect its expansion into higher education. ${ }^{19}$ In 1989, the Spanish Eastern District of the Assemblies of God (SED) opened the Escuela de Teología de las Asambleas de Dios and was led for many years by Rev. Dr. Alvin Padilla. Padilla finalized a partnership with Nyack College (CMA) and Valley Forge Christian College (AG) to offer undergraduate theological education (Diaz 1995, pp. 74-75). Notable graduates of the Escuela de Teología include Dr. Juan Hernandez, who graduated from Emory University with distinction, Professor of New Testament at Bethel University, and current member of the editorial board for the Journal of Biblical Literature.

\subsection{Oppression of Voicelessness}

The Kingdom activity highlighted thus far confronts the systems and institutions of oppression indirectly. However, US Latinx Pentecostalism has a legacy of direct action and confrontation of the powers and principalities of this age. At times, the actions address specific issues. Other times, action is taken merely to affirm the place and voice of communities that find themselves oppressed. The latter was the goal in 1932 when Rev. Francisco Olazabal organized and led the first March for Jesus in New York City. In the aftermath of the great stock market crash of 1929 and the Great Depression, New York City Puerto Ricans were experiencing violence borne from nativist resentment. Although the march did not explicitly emphasize civil rights or racism, it served to communicate the presence and humanity of the growing Puerto Rican population and to protest the increasing violence against it. The most militant actions taken by anyone connected with Latinx Pentecostalism were those previously described perpetrated by Reies Lopez Tijerina. In 1965, Tijerina, a former Pentecostal pastor, along with the organization he led, the Alianza Federal de Mercedes Rosales, reclaimed 500,000 acres and occupied the Echo Amphitheater campground at Carson National Forest, New Mexico. Two years later, he raided a New Mexico courthouse. Both of these actions had to do with land grant issues in which Mexican Americans who held titles for land that belonged to their families less than one hundred years prior had their lands appropriated by Anglos while the "justice" system looked the other way.

In 1999, David Sanes Rodriguez was killed on the island of Vieques in Puerto Rico during a Naval bombing exercise. This became the rallying cry for citizens who had been requesting an end to the US military exercises for decades and were being ignored. For many years, high rates of cancer and other terminal illnesses were also attributed to the military presence. In 2000, the Ecumenical Coalition of Churches for Vieques (ECCV) was formed. Pentecostal Pastor Wilfredo Estrada was elected as the first president and soon thereafter led a protest march for the cause of the people of Vieques. In 2001, Bronx Borough President Adolfo Carrion, Jr., Rev. Al Sharpton, Rev. Wilfredo Estrada, and ECCV pastors were arrested in Vieques for protesting the resumption of Navy bombing exercise ${ }^{20}$ As a result of their efforts, in 2003, President George W. Bush permanently closed down the US Naval base in Vieques, PR.

After the 9/11 attacks in 2001, Pentecostal Pastor Rev. Dr. Marc Rivera established the Northeast Clergy Association to train pastors to work with families impacted by the 9/11 attacks. This network has since engaged in other issues affecting the communities of color in New York City. In 2006, RadioVision Cristiana, Rev. Raymond Rivera's Latino Pastoral Action Center (LPAC), and State Senator Ruben Diaz, Sr., organized a rally for immigration reform in Brooklyn Bridge, where over 20,000 people from diverse communities joined for this cause. 
Oppression of racism in the church, ideological oppression through educational and denominational institutions that impose notions of racial hierarchies and domination, and other injustices are all systems and structures that the Pentecostals ministers and scholars as well as Liberation Theologians believe that the Kingdom exposes and confronts. Through a dependence on the Spirit, US Latino Pentecostalism has intuitively confronted these various forms. Although Latinx Pentecostal scholarship is making efforts to understand what has happened throughout its history and to expose the holistic nature of the Spirit's work within it, more needs to be done in order to get that message through multi-pronged approaches to the US Latinx Pentecostal community that is not in the academy. Producing materials for its Bible institutes may be a way to do it. In this case, it is possible that Latinx Pentecostal scholarship needs to follow the steps established by Rev. Dr. Jesse Miranda, who, until recently, has written primarily for ministers. As a result, some of his material is used in Bible institutes.

\section{Conclusions}

The works of Gause, Macchia, and Yong demonstrate an evolution in the US Pentecostal understanding of the Kingdom from one that is more individualistic to one that increasingly social in nature. Their work also demonstrates how Pentecostalism has always acknowledged the importance of the present-day emphasis of the Kingdom in the Scriptures. Yet, increasing awareness of both the social nature and the present-day emphasis of Kingdom theology has not resulted in engagement in the public sphere by Pentecostals with the exception of "culture wars" issues in recent decades.

However, as the lives of Tijerina, Olazabal, and others before them demonstrate that from its origins, absence from the public sphere was not the case within US Latinx Pentecostalism, despite the lack of an articulated Kingdom theology of social engagement. For US Latinx Pentecostals, public engagement was not usually a matter of choice or a struggle for power among equals. It was part of the struggle for survival and the right to express the full humanity and spirituality of people of diverse Latin American backgrounds that found themselves in contexts of oppression, racism, marginalization, and subordination in society and their respective ecclesiastical contexts at the local and denominational levels. The history of struggle produced a holistic existential theology of the Kingdom, which, in turn, intuitively led ministers to establish, for example, one of the first drug recovery organizations and ministries in the New York City area and one of the first Latinx owned and operated advocacy and care organizations for people dying from HIV / AIDS.

This struggle preceded US Latinx Pentecostal scholarship. In fact, the first US Latinx Pentecostal scholars emerged from this context, one in which the challenges facing the US Latinx communities were always at the forefront. Consequently, scholars such as Villafañe have always sought to maintain their scholarship connected to and at the service of the church. The notion of the academy being at the service of the Church will be increasingly critical for the church in the coming years, as it will confront the possibility of great changes in immigration laws, demographics, and foreign policy relationships with Latin American nations.

It is important to note that while Orlando Costas exposed Latinx Pentecostal scholars and practitioners to Liberation Theology from an evangelical perspective and Latin American Liberation Theology helped them to develop a clearer articulation of Kingdom themes (i.e., liberation or the preferential option for the poor), many of these themes were already existentially present in the US Latinx Pentecostal tradition. This can be seen in the lives of figures such as Francisco Olazabal, Juan Lugo, Leoncida Rosado, “Mama Leo", and others. Predating Liberation Theology, Reies Lopez Tijerina's 1950s sermon collections articulated a theology of justice that is consistent with the social implications of the Kingdom as understood by Liberation Theologians and the Pentecostal scholars and ministers discussed in this paper. These were intuitive Kingdom expressions that have often been attributed to the giftings of individuals. Instead, they should be seen as a community legacy to be built 
upon and imitated. Pentecostals would more likely describe these experiences as having been moved by the Spirit to do the work of the Kingdom. However, if they draw from a more holistic theology of the Kingdom, one that integrates traditional Pentecostalism and Latin American Liberation Theology, as well as from the history of radical actions by Latinx Pentecostals, Latinx Pentecostal scholarship can partner with the Latinx Pentecostal church practitioners to recover, define, and transmit the history of a lived Kingdom theology that impacts lives and communities. This, in turn, can help Latinx Pentecostals move towards a more holistic and intentional expression of the Kingdom and Reign of God that confronts injustice and oppression in all its forms with its unique spiritual resources.

Funding: This research received no external funding.

Conflicts of Interest: The author declares no conflict of interest.

\section{Notes}

1 Recently, scholar/practitioners such as Soong-Chan Rah have started to address the implications of Western individualism in the life of the evangelical church. See, The Next Evangelicalism: Freeing the Church form Western Cultural Captivity. Downer's Grove: InterVarsity Press, 2009.

2 General Presbytery of the Assemblies of God, 4 August 1989. "The Kingdom of God as Described in Holy Scripture", Positions Papers. p. 1. Internet resource-http://www.ag.org/top/Beliefs/Position_Papers/pp_downloads/pp_4190_kingdom.pdf (accessed on 28 May 2011).

3 CI Scofield. Scofield Reference Bible. 1966. New York: Oxford University Press, p. 950.

4 General Presbytery of the Assemblies of God, 4 August 1989. “The Kingdom of God As Described in Holy Scripture”, Positions Papers. p. 2. Internet resource-http://www.ag.org/top/Beliefs/Position_Papers/pp_downloads/pp_4190_kingdom.pdf (accessed on 28 May 2011).

Ibid.

Ibid.

For his own autobiography see, (Tijerina 2000). For a more recent and critical assessment of Tijerina's life and work see, (Oropeza 2019).

8 Latino Pastoral Action Center Information Booklet p. 12.

9 http://www.cts.edu/Forms/Encounter/63--1Alvarez.pdf pp. 21-23. (accessed on 21 May 2011)

10 http://www.patchoguecoc.org/way_out_ministries.htm. (accessed on 21 May 2011)

11 http://www.esperanza.us/site/c.giKPL8PQLvF/b.3916629/k.642E/Esperanza_Esperanza_usa_esperanza_us.htm. (accessed on 21 May 2011)

12 https://www.radiovision.net/sobre-nosotros (accessed on 28 May 2011)

13 https://www.radiovision.net/sobre-nosotros (accessed on 28 May 2011)

14 Ibid.

15 Ibid.

16 Ibid

17 http:/ / www.mizpa.edu/portal/archives/3082 (accessed on 28 May 2011)

18 http://www.hispanicsummerprogram.org/. (accessed on 28 May 2011)

19 http://www.mizpa.edu/portal/archives/3082 (accessed on 28 May 2011)

20 http://www.nytimes.com/2001/05/24/nyregion/sharpton-and-3-from-bronx-are-jailed-in-vieques-protest.html. (accessed on 21 May 2011)

\section{References}

Barth, Karl. 1997. The Holy Spirit and the Christian Life. Louisville: Westminster John Knox Press.

Boff, Leonardo, and Clodivis Boff. 2004. Introducing Liberation Theology. Maryknoll: Orbis Books.

Bonino, Jose Miguez. 1975. Doing Theology in a Revolutionary Situation. Philadelphis: Fortress Press.

Busto, Rudy. 2005. King Tiger: The Religious Vision of Reies Lopez Tijerina. Albuquerque: University of New Mexico Press.

Conde-Frazier, Elizabeth. 2005. Hispanic Bible Institutes: A Community of Theological Construction. Scranton: University of Scranton Press.

Costas, Orlando. 1982. Christ Outside the Gate. Maryknoll: Orbis Books, pp. 86-99.

Crespo, Orlando. 2003. Being Latino in Christ. Downers Grove: InterVarsity Press.

Denis, Nelson A. 2015. The War Against All Puerto Ricans: Revolution and Terror in American's Colony. New York: Nation Books.

Diaz, Samuel. 1995. La Nave Pentecostal. Deerfield: Editorial Vida.

Erickson, Millard J. 1985. Christian Theology. Grand Rapids: Baker Book House. 
Espinosa, Gastón. 1999. El Azteca: Francisco Olazabál and Latino Pentecostal Charisma, Power, and Faith Healing in the Borderlands. Journal of the American Academy of Religion 67: 597-616. [CrossRef]

Espinosa, Gaston, Virgilio Elizondo, and Jesse Miranda. 2005. Latino Religions and Civic Activism in the United States. Oxford: Oxford University Press.

Fackre, Gabriel. 1989. Evangelical Hermeneutics: Commonality and diversity. Interpretation (Richmond) 43: 120. [CrossRef]

Garcia-Treto, Francisco. 1999. Reading the Hyphens: An Emerging Biblical Hermeneutics. Edited by David Maldonado Jr. Protestantes/Protestants. Nashville: Abingdon Press, pp. 163-64.

Gause, R. Hollis. 2020. The Lukan Transfiguration Account: The Exalted Lord in the Glory of the Kingdom of God. Cleveland: CPT Press, p. 92.

General Council of the Assemblies of God. n.d. Statement of Fundamental Truths. Available online: http://ag.org/top/Beliefs/ Statement_of_Fundamental_Truths/sft_full.cfm\#7 (accessed on 1 June 2021).

Gutierrez, Gustavo. 1973. A Theology of Liberation. Maryknoll: Orbis Books, p. 122.

Johnston, Robert Kent. 1982. Interpreting Scripture Literary-Criticism and Evangelical Hermeneutics. Christianity and Literature 32: 33-47. [CrossRef]

Latino Pastoral Action Center. n.d. Latino Pastoral Action Center Information Booklet. New York: Latino Pastoral Action Center.

Macchia, Frank D. 2006. Baptized in the Spirit: A Global Pentecostal Theology. Grand Rapids: Zondervan.

Machado, Daisy. 2006. “El Gran Avivamiento del '33”. In Futuring Our Past. Edited by Orlando O. Espin and Gary Macy. Maryknoll: Orbis Books, p. 269.

Oropeza, Lorena. 2019. The King of Adobe: Reies Lopez Tijerina, Lost Prophet of the Chicano Movement. Chapel Hill: University of North Carolina Press.

Sanchez-Walsh, Arlene. 2000. Workers for the Harvest. Journal of Hispanic/Latino Theology 8: 1.

Sanchez-Walsh, Arlene. 2003. Latino Pentecostal Identity: Evangelical Faith, Self, and Society. New York: Columbia University Press.

Sobrino, Jon. 1993. Jesus the Liberator. Maryknoll: Orbis Books.

Sobrino, Jon. 2008. No Salvation Outside the Poor. Maryknoll: Orbis Books, p. 78.

Solivan, Samuel. 1996. Sources of Hispanic/Latino Theology: A Pentecostal perspective. In Hispanic/Latino Theology: Challenge and Promise. Minneapolis: Fortress Press.

Solivan, Samuel. 1997. The Holy Spirit: A Pentecostal perspective. In Teologia en Conjunto: A Collaborative Hispanic Protestant Theology. Edited by Jose David Rodriguez and Loida I. Martell-Otero. Louisville: Westminster John Knox Press, p. 62.

Solivan, Samuel. 1998. The Spirit, Pathos and Liberation: Toward an Hispanic Pentecostal Theology. Sheffield: Sheffield Academic Press.

Thomas, Piri. 1972. Savior, Savior, Hold My Hand. New York: Doubleday \& Co.

Tijerina, Reies Lopez. 2000. They Called Me "King Tiger": My Struggle for the Land and Our Rights. Houston: Arte Publico Press.

Traverso-Galarza, David. 1997. Sin: A Hispanic Perspective. In Teologia en Conjunto: A Collaborative Hispanic Protestant Theology. Edited by Jose David Rodriguez and Loida I. Martell-Otero. Louisville: Westminster John Knox Press.

Villafañe, Eldin. 1993. The Liberating Spirit: Toward a Hispanic Pentecostal Social Ethic. Grand Rapids: William B. Eerdman's Publishing Company.

Villfañe, Eldin. 1995. Seek the Peace of the City: Reflections on Urban Ministry. Grand Rapids: William B. Eerdman's Publishing Company.

Villafañe, Eldin. 2001. A Prayer for the City: Further Reflections on Urban Ministry. Austin: Asociacion para la Educacion Teologica Hispana, p. 23.

Villfañe, Eldin. 2006. Fe, Espiritualidad y Justicia: Teologia Posmoderna de un Boricua en la Diaspora. Rio Piedras: Librería Palabra y Mas.

Villafañe, Eldin, Bruce W. Jackson, Robert A. Evans, and Alice Frazer Evans. 2002. Transforming the City. Grand Rapids: William B. Eerdman's Publishing Company.

Weber, Max. 1978. Economy and Societ. Edited by Guenther Roth and Claus Wittich. Berkeley: University of California Press, pp. 439-67.

Yong, Amos. 2005. The Spirit Poured Out on All Flesh: Pentecostalism and the Possibility of a Global Theology. Grand Rapids: Baker Academic Press. 